\title{
Regional climate change scenarios over southern South America for future climate (2080-2099) using the MM5 Model. Mean, interannual variability and uncertainties
}

\author{
MARÍA FERNANDA CABRÉ \\ Centro de Investigaciones del Mar y la Atmósfera (CIMA-CONICET/FCEN-UBA); \\ Instituto Franco Argentino de Estudios del Clima y sus Impactos (UMI IFAECI/CNRS), Ciudad Universitaria, \\ pabellón II, piso 2, C1428EGA, Buenos Aires, Argentina \\ Corresponding author; e-mail: cabre@cima.fcen.uba.ar
}

\begin{abstract}
SILVINA SOLMAN and MARIO NÚÑEZ
Centro de Investigaciones del Mar y la Atmósfera (CIMA-CONICET/FCEN-UBA); Departamento de Ciencias de la Atmósfera y los Océanos (DCAO/FCEN-UBA); Instituto Franco Argentino de Estudios del Clima y sus Impactos (UMI IFAECI/CNRS), Ciudad Universitaria, pabellón II, piso 2, C1428EGA, Buenos Aires, Argentina
\end{abstract}

Received: February 3, 2015; accepted: November 9, 2015

\begin{abstract}
RESUMEN
Este trabajo evalúa las proyecciones de cambio climático del modelo regional MM5 para fines del siglo veintiuno en el escenario de emisión SRES A2 en el sur de Sudamérica. El modelo proyecta: (i) aumento de la precipitación en el centro de Argentina, Uruguay y sur de Brasil en verano y otoño; (ii) disminución de la precipitación en la mayor parte de la región de estudio en invierno y primavera; (iii) marcada reducción de la precipitación en el centro y sur de Chile durante todo el año. En general, el aumento de temperatura proyectado depende de la época y la región examinada; particularmente es máximo en latitudes tropicales y subtropicales en primavera y en altas latitudes en verano. El modelo MM5 proyecta: (i) aumento de la variabilidad interanual de la precipitación en el centro de Argentina y Uruguay independientemente de la época del año; (ii) una leve disminución de la variabilidad interanual de la temperatura en la mayor parte de territorio argentino para verano e invierno; (iii) un leve aumento de la variabilidad interanual de la temperatura en las estaciones intermedias; con valores mayores en el centro de Chile en otoño y en el centro norte de Argentina en primavera. De la evaluación de cuán robustas son las proyecciones climáticas regionales, puede concluirse que la relación señal-ruido es alta para la temperatura y baja para la precipitación. Por lo tanto, el modelo MM5 es una herramienta de mucha utilidad para la generación y evaluación de escenarios regionales de cambio climático en el sur de Sudamérica, en especial para la temperatura. Esto constituye un punto de partida para realizar estudios relacionados con el impacto del cambio climático.
\end{abstract}

\section{ABSTRACT}

This work focuses on evaluating the climate change projected by the end of the 21 st century under the SRES A2 emission scenario over southern South America using the regional model MM5. The model projects: (i) an increase of precipitation over central Argentina, Uruguay and southern Brazil during summer and fall; (ii) a decrease in precipitation over most of the study domain during winter and spring; (iii) an important decrease in precipitation over central and southern Chile, through the year. In general, the projected temperature increase depends on the season and the examined area; particularly, it is highest over tropical and subtropical latitudes in spring and over high latitudes in summer. The MM5 model projects: (i) an increase of the interannual precipitation variability of precipitation over central Argentina and Uruguay regardless the season; (ii) a slight decrease in interannual temperature variability over large extents of Argentina for summer and winter; (iii) a slight increase in interannual temperature variability at transition seasons; with highest values 
over central Chile in autumn and over north central Argentina in spring. From the reliability assessment of regional climate projections, it can be concluded that signal-to-noise ratio is high for temperature and low for precipitation. Therefore, the MM5 model is a useful tool in the generation of regional climate change scenarios of high resolution over southern South America, particularly for temperature, and is a starting point to perform studies related to impacts of climate change.

Keywords: Regional climate modeling, South America, climate change scenarios, uncertainties.

\section{Introduction}

Current global climate simulations can reproduce relatively well features of general circulation throughout the world (Mizuta et al., 2006; Randall et al., 2007; Vera and Silvestri, 2009; Blázquez and Núñez, 2012a; Cavalcanti and Shimizu, 2012; Rupp et al., 2013; Grose et al., 2014; Gulizia and Camilloni 2015, among others). Nevertheless, their performance deteriorates when looking at finer temporal and spatial scales, which are needed for impact assessment studies on natural environments such as agriculture (Jones and Thornton, 2003); biogeography and ecology (Diniz Filho et al., 2009; Wiens et al., 2009); hidrology and water resource management (Wood et al., 2004; Kotlarski et al., 2005; Buytaert et al., 2009; Kay et al., 2009; Laghari et al., 2012), and oceanography and glaciology (Good et al., 2009; Holland et al., 2010; Vizcaíno et al., 2010).

Due to the need for an analysis of climate change at a regional scale, the use of regional climate models (RCMs) for dynamical downscaling were developed to obtain detailed information from general circulation models (GCMs). The most recent report from the IPCC (Flato et al., 2013) shows that the number of regional climate modeling studies throughout the world has increased during the last decade. Moreover, the research community has made great efforts to improve RCMs, for example increasing their resolution, further developing process descriptions, and adding new components. As a consequence, RCMs are regularly tested to evaluate whether they show improvements over global models (Laprise et al., 2008; Rummukainen, 2010).

Dynamical downscaling experiments of climate change scenarios have become available over Europe (Christensen et al., 2001; Giorgi et al., 2004; Gao et al., 2006; Beniston et al., 2007; Christensen et al., 2007a, b; Krichak et al., 2007; Tapiador and Sánchez, 2008; Pieczka et al., 2011; Brankovic et al., 2012; Gaertner et al., 2012), North America (Pan et al., 2001; Liang et al., 2004), Australia (Whetton et al., 2001), Africa (Arnell et al., 2003; Tadross et al., 2005), and Asia (Rupa Kumar et al., 2006; Im et al., 2007; Islam et al., 2008; Islam and Rehman, 2009; Islam et al., 2009; Koo et al., 2009; Chotamonsak et al., 2010; Saeed et al., 2013). Particularly over South America, several publications can be mentioned: Marengo and Ambrizzi (2006), Solman et al. (2007), Garreau and Falvey (2008), Núñez et al. (2008), Marengo et al. (2009, 2010), Soares and Marengo (2009), Urrutia and Viulle (2009), Sörensson et al. (2010), and Cabré et al. (2010, 2014) for SRES A2 and SRES B2; Marengo et al. (2012), Franchito et al. (2014), and Reboita et al. (2014) for A1B; and Teichmann et al. (2013), Chou et al. (2014) for the new set of scenarios termed as representative concentration pathways (RCPs).

However, due to the complexity of the climate system and modeling processes, relationships between uncertainty types must be considered. Uncertainty in future climate change derives from three main sources: (i) forcing, (ii) model response, and (iii) internal variability (Hawkins and Sutton, 2009). The first arises from incomplete knowledge of external factors influencing the climate system, including future trajectories of anthropogenic emissions of greenhouse gases (GHGs), stratospheric ozone concentrations, land use change, etc. The second occurs because different models may yield different responses to the same external forcing as a result of differences in, for example, physical and numerical formulations. The third is the natural variability of the climate system that occurs in absence of external forcing, also termed "climate noise", and includes processes intrinsic to the atmosphere, the ocean, and the coupled ocean-atmosphere system (Deser et al., 2012). Consequently, uncertainties studies of global (Giorgi and Mearns, 2002; Hawkins and Sutton, 2009; Hawkins and Sutton, 2011; Räisänen, 2006; Blázquez et al., 2012; Blázquez and Núñez, 2012b; Deser et al., 2012; Torres and Marengo, 2013) and regional climate change projections (Mitchell and Hulme, 1999; Giorgi and Francisco, 2000; Monier et al., 2013; Solman et al., 2013) can be found all over the world. 
Therefore, uncertainties associated with RCMs outputs must be taken into account, as they can be quantified and minimized to provide valuable information for decision-making (Foley, 2010). In order to provide a full quantification of uncertainties in the projected regional climate and useful information for impact studies, the broad range of uncertainties should be considered. For the purpose of reducing uncertainties associated with RCMs, several methodologies have been implemented: (i) multimodel ensembles (Doblas-Reyes et al., 2005), which attribute the improvement to the use of different models and increased ensemble size and are useful to characterize intermodel variability; and (ii) perturbed physics ensembles, since an ensemble may also consist of different runs of the same model, each with perturbed versions of the original model physics. This approach is highly useful for quantifying variability within the model. However, the optimal approach would be to use a multimodel perturbed-physics ensemble. For instance, the generation of ensembles performed with different RCMs simulations nested into different GCMs under different emission scenarios is an approach that has been followed by several international efforts, such as the projects PRUDENCE (Déqué et al., 2005; Gao et al., 2006; Christensen et al., 2007a, b), ENSEMBLES (Hewitt, 2005), STARDEX (Haylock et al., 2006) and CORDEX (Jacob et al., 2013) for Europe; CORDEX (Giorgi et al., 2009) for Africa; and CLARIS LPB (Solman et al., 2013) and CORDEX (Solman, 2013) for South America.

This paper presents an analysis of climate change over southern South America based on the MM5 regional model simulation. The regional model was driven by global atmospheric model HadAM3H under the SRES A2 scenario. It is focused on seasonal mean precipitation and near-surface temperature, because these variables are useful for impact studies. Therefore, based on the need of detailed information on climate change projections, it performs an assessment of climate change projections and associated uncertainties over southern South America. This article is organized as follows: section 2 gives a brief summary of some characteristics of the regional model configuration and an update on the new set scenarios from the AR5 (IPCC, 2013). Results are found in section 3; firstly a brief evaluation of uncertainties in future regional climate projections is found in section 3.1, where the reliability of predictions is explored measured by the signalto-noise ratio; the spatial distribution of changes of surface variables in mean climate is found in section 3.2; the statistical significance of seasonal changes was determined using Student's $t$ test at a confidence level of $95 \%$, and analyzed jointly in this section; furthermore, section 3.3 presents the analysis of changes in the annual cycle, and section 3.4 presents the analysis of spatial distribution of changes in interannual temperature and precipitation variability. Finally, the most important conclusions are summarized in section 4 .

\section{Model description, experiment design and scenarios}

\subsection{The regional model MM5}

The regional climate simulation was performed using the fifth-generation nonhydrostatic mesoscale model MM5 version 3.6 (the latest version available at the time of starting the experiment design) developed by Penn State University (PSU) and the National Centers for Environmental Prediction/National Centre for Atmospheric Research (NCEP/NCAR) (Grell et al., 1993). Details of the regional model configuration used to perform the continuous 20-year simulation are found in Cabré et al. (2014). It includes the Grell convective scheme (Grell et al., 1993), and the planetary boundary layer parameterization is formulated following the MRF scheme by Hong and Pan (1996). Surface processes are represented by the Noah land surface model (Chen and Dudhia, 2001). Moisture tendencies were calculated with an explicit moisture scheme (Hsie et al., 1984). The calculation of radiative heating or cooling in the atmosphere accounts for longwave and shortwave interactions with explicit clouds and clear air. The radiation package calculates long-wave radiation through clouds and water vapor, based on Stephens (1978, 1984) and Garrand (1983); it also accounts for short wave absorption and scattering in clear air, and reflection and absorption in cloud layers Stephens (1984). The nonhydrostatic dynamics allow it to be used effectively to represent phenomena with very few kilometers of resolution. The surface model Noah LSM has been implemented to improve the representation of surface processes. Moreover, the MM5 model requires initial and time evolving boundary conditions for wind components, temperature, geopotential height, relative humidity 
and surface pressure. These variables were provided in a six-hourly interval within a relaxation zone in the lateral boundaries.

The regional model was run in a Mercator grid with approximately $40 \mathrm{~km}$ resolution in both horizontal directions, with 158 points in the west-east direction and 150 points in the south-north direction, and with 23 sigma levels in the vertical direction. The land sea mask and topography have been derived from the US Navy $10 \mathrm{~min}$ resolution dataset. Vegetation and soil properties were obtained from USGS vegetation/land use database.

The integration domain covers southern South America, from 12 to $58^{\circ} \mathrm{S}, 28$ to $92^{\circ} \mathrm{W}$. The model topography and the study domain are displayed in Figure 1. It can be seen that the selected domain covers the whole of Argentina and is expected to capture the regional climate resulting from the interactions of large-scale and local circulation.

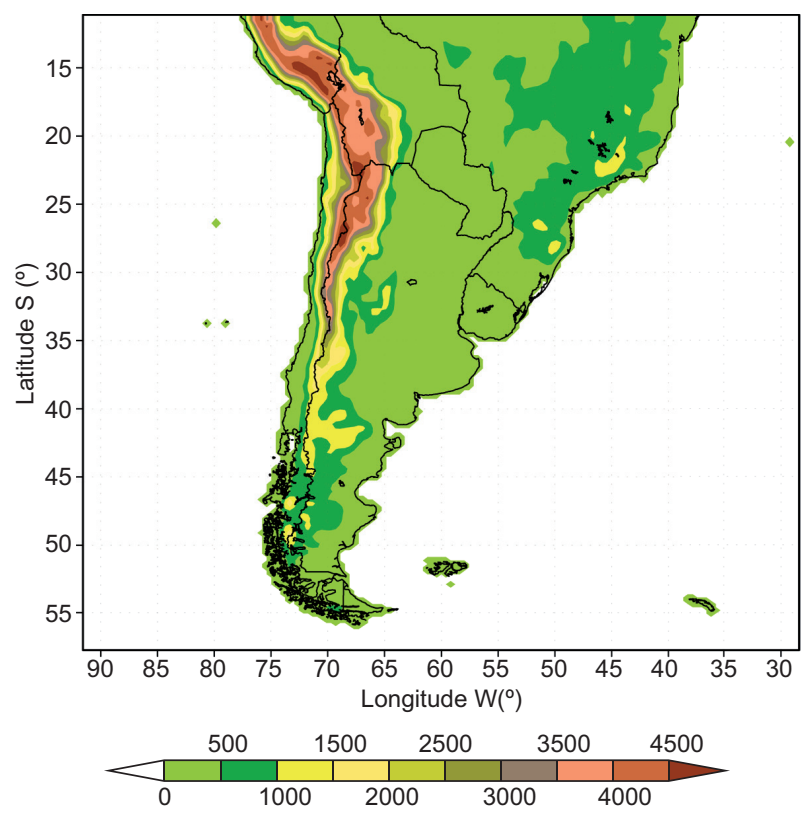

Fig. 1. Model domain and topography of the MM5 regional climate model. Contours are drawn every $500 \mathrm{~m}$.

\subsection{Boundary conditions and experiment design}

The MM5 model is forced by global atmospheric model HadAM3H. Regarding future simulation (2080-2099), the global model has been forced by sea surface temperature (SST) calculated using the observed SST and modified by the sum of mean change and the trend obtained from the coupled global model projection. The integration was performed with the coupled HadCM3 model (Gordon et al., 2000).

The experimental design of the regional simulation for present climate (1970-1989) started on January 1, 1969 up to December 1, 1989. A oneyear spin-up time was adopted (Christensen, 1999) for surface variables (such as soil moisture and soil temperature for different sub levels between 1 and $2 \mathrm{~m}$ ) from the land surface model. Likewise, the regional climate simulation for future climate started on January 1, 2079 up to December 1, 2099. As for the present climate simulation, a one-year spin-up time was adopted (Christensen, 1999).

The HadAM3H model has a $1.25^{\circ}$ latitude by $1.875^{\circ}$ longitude resolution; details of its characteristics can be found in Pope et al. (2000). The HadAM3H climate simulations from 1961 to 1990 were initialized with atmospheric and land surface conditions from the Coupled Ocean-Atmosphere Global Climate Model (HadCM3) from the Hadley Centre and forced with observed SST and sea-ice distribution from the HadISST dataset (Rayner et al., 2003). This database shows a mixture of global monthly SST and sea ice concentration at $1^{\circ}$ horizontal resolution from 1871 .

\subsection{Scenarios vs. representative concentration pathways}

In the AR4 (IPCC, 2007), emission scenarios were built based on the storylines grouped into a more economically concerned development or a more environmental and sustainable development; also into a more globalized world or a more regionally developing world. In the AR5 (IPCC, 2013), scenarios are based on total anthropogenic radiative forcings at the end of the 21 st century. Economic models can take different paths to reach four different radiative forcings that are equivalent to different concentration paths of greenhouse gases (GHGs), the so-called RCPs. The four different scenarios are labeled as: RCP 8.5, RCP 6.0, RCP 4.5, and RCP 2.6, which correspond to radiative forcings of $8.5,6.0,4.5$, and $2.6 \mathrm{~W} \mathrm{~m}^{-2}$, respectively. The first RCP is the most pessimistic scenario, resulting in a global average warming at the end of the 21 st century of about $4{ }^{\circ} \mathrm{C}$, whereas the last RCP is the most optimistic and corresponds to a global warming of about $1{ }^{\circ} \mathrm{C}$. Radiative forcing in RCP 8.5 corresponds approximately to A2 scenario in AR4 (IPCC, 2007). Particularly, 
SRES A2 has a similar trajectory to that of RCP8.5, with both reaching about $8 \mathrm{~W} \mathrm{~m}^{-2}$ by 2100 . SRES A2 is also similar to RCP 8.5 in terms of changes in global mean temperature. For instance, for RCP 8.5, global mean surface temperatures for 2081-2100, compared to those for 1986-2005, are likely to be in the range of 2.6 to $4.8^{\circ} \mathrm{C}$, with a multi-model mean increase of $3.7^{\circ} \mathrm{C}$. The projected warming for SRES A2 for the 2090-2099 period, relative to 1980-1999, is given by IPCC AR4 as 2.0 to $5.9{ }^{\circ} \mathrm{C}$, with a best estimate of $3.4^{\circ} \mathrm{C}$ (IPCC, 2013).

\section{Results}

3.1. Analyses of uncertainties, changes of mean climate vs. interannual variability

This section assesses the uncertainties associated with climate projections of seasonal temperature and precipitation over southern South America by the end of 21 st century. The objective is to identify how robust is the projected change compared to interannual variability, which is a measure of the inherent natural variability of the system or noise. Therefore, a key question is how reliable climate models are or how much we can trust on these projections. Identifying which areas and for what variables uncertainties are larger means that the regional simulation may be less reliable. In order to interpret climate statistics correctly, the definitions of climate change, signalto-noise ratio and statistical significance have been studied for several authors (Hayashi, 1982, and references therein). Accordingly, the significance of projected changes is evaluated by the signal-to-noise ratio defined by the following equation:

$R_{\mathrm{var}}=\frac{\left|\Delta \overline{V A R}_{\text {future }- \text { present }}\right|}{S T D V_{\mathrm{var}}}$

where var represents either surface air temperature or precipitation; $\Delta \overline{V A R}_{\text {future - present }}$ is the signal of climate change (defined as the difference between the climate in the scenario simulation and present climate simulation) and $S T D V_{\text {var }}$ is the interannual variability, as a measure of noise (computed as the standard deviation of projections). $R_{\mathrm{var}}$ greater than 1 indicates that the signal of climate change is greater than the interannual variability, consequently the signal of climate change is robust, which relates with areas of low uncertainty and likewise to more confident projections; whereas $R_{\text {var }}$ lower than 1 indicates that the signal of climate change is lower than the interannual variability (noise dominates), consequently the signal of climate change is not robust, which relates with areas of high uncertainty.

Figure 2 displays the spatial distribution of signalto-noise ratio for mean precipitation changes $\left(R_{\text {precip }}\right.$, left column $)$ and for mean temperature changes $\left(R_{\text {temp }}\right.$, right column) for all seasons.

The analysis of reliability is summarized for four regions: (1) subtropical latitudes, (2) Uruguay-southern Brazil, (3) east-central Argentina, and (4) central and southern Chile. For precipitation, the magnitude of climate change is lower than the amplitude of interannual variability throughout the year over the entire domain. This suggests that precipitation projections are less reliable all year long over southern South America. However, few regions were identified where the signal was greater than the noise: south-central Argentina in summer and north-western Argentina and Peru in winter. On the other hand, the signal of climate change in temperature seems to show a general opposite behavior. It is greater than interannual variability all over the domain in all seasons, coinciding with areas of more confident projections. Particularly, temperature projections are robust over east-central Argentina and Uruguay-southern Brazil, with highest values of $R_{\text {temp }}$ over subtropical latitudes during summer. In winter, temperature projections are reliable over north-western Argentina, northern Chile, western Bolivia and subtropical latitudes. On the other hand, temperature projections are less reliable over east-central Argentina and Uruguay-southern Brazil during winter. The autumn pattern of $R_{\text {temp }}$ is similar to that of spring. Particularly, reliability of temperature projections is high over northern Argentina, Uruguay-southern Brazil, and subtropical latitudes, and it is low over the rest of the study domain.

Consequently, the reliability of temperature projections is high, with signal-to-noise ratio greater than 1 over most of the study domain. On the other hand, the reliability of precipitation projections was low. However, the signal-to-noise ratio was close to 1 , and even greater than 1 over southeastern Argentina in summer. Figure 3 summarizes the important findings of climate projections reliability over southern South America by the end of the 21 st century. 

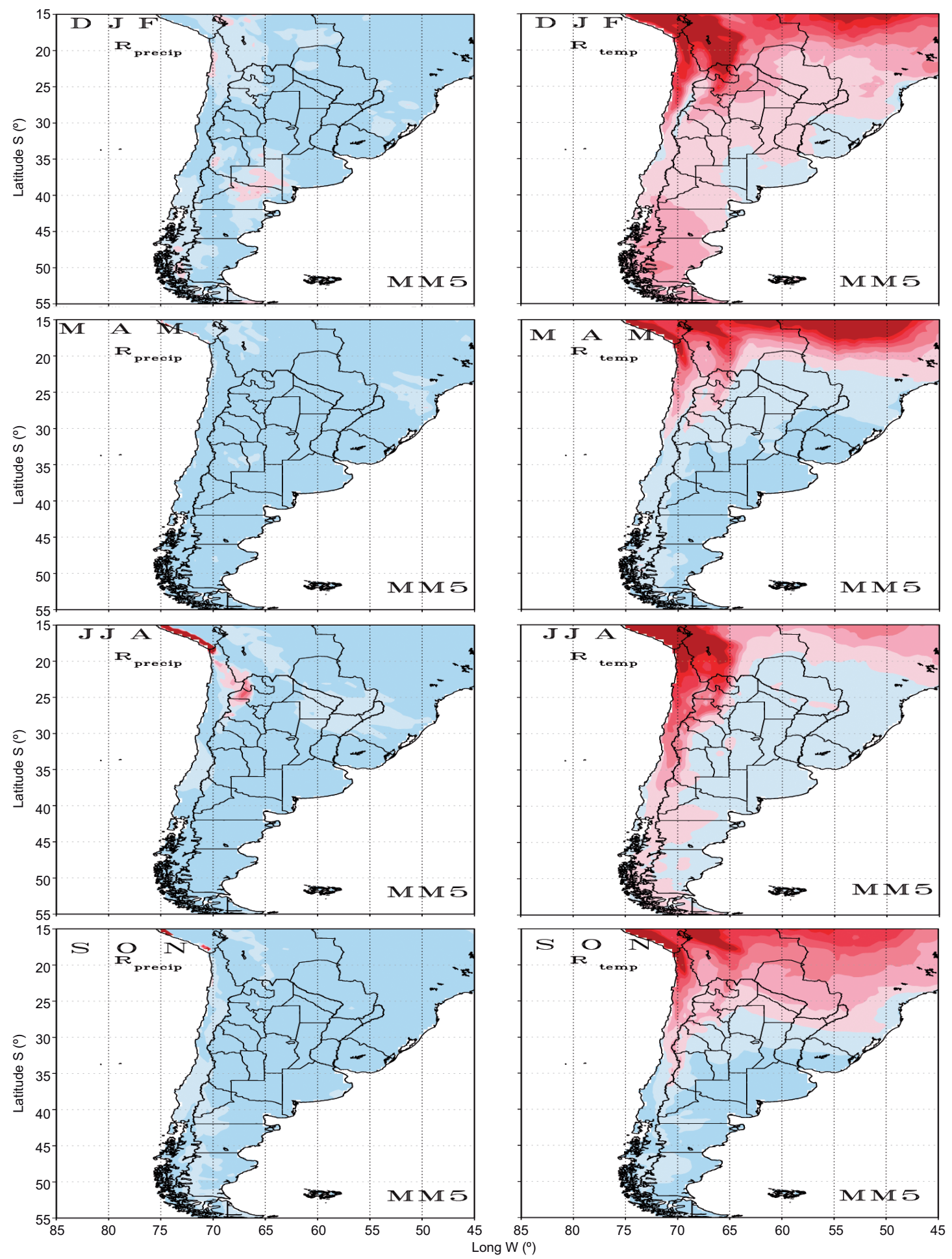

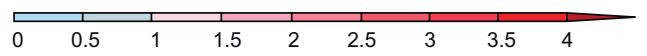

Fig. 2. Signal-to-noise ratio for precipitation $\left(R_{\text {precip }}\right.$, left column) and temperature $\left(R_{\text {temp }}\right.$, right column) by the end of the 21 st century during summer (DJF), autumn (MAM), winter (JJA) and spring (SON). Dimensionless coefficient. 


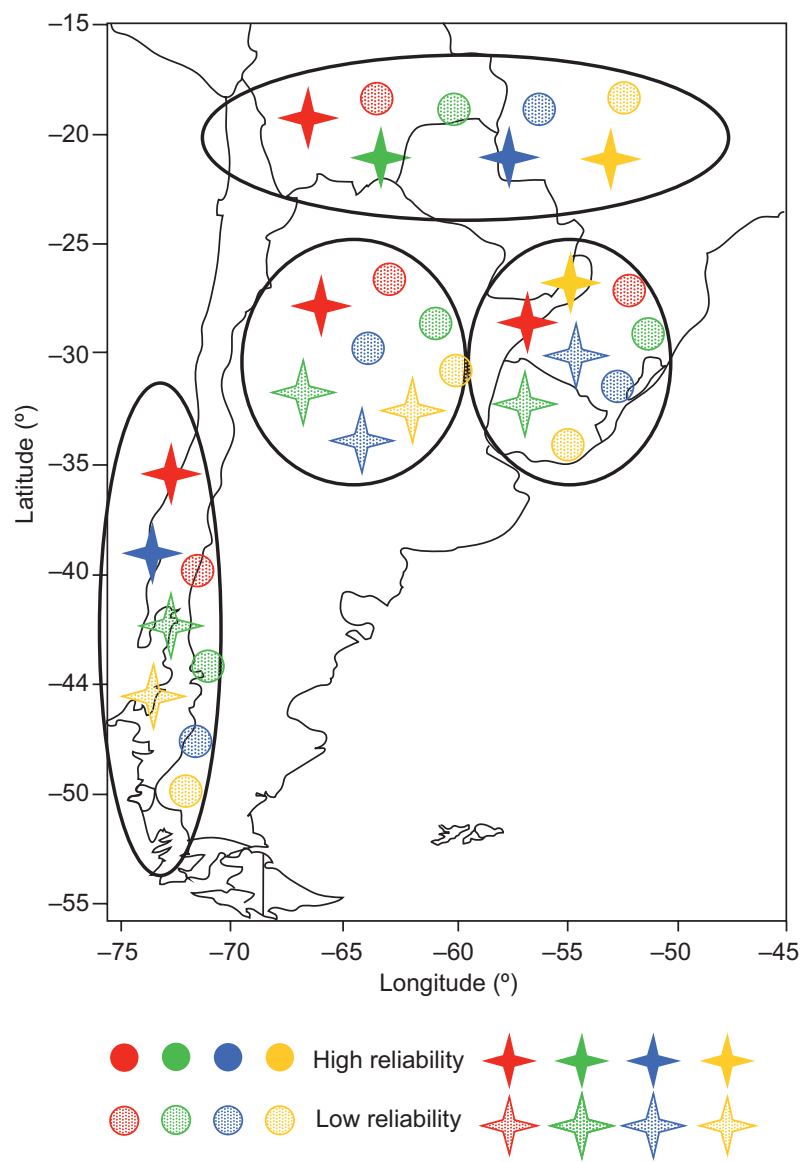

Fig. 3. Schematic graph of the MM5 regional model reliability for climate change on precipitation (circles) and temperature (stars). Red: DJF; green: MAM ; blue: JJA; orange: SON.

\subsection{Changes in mean climate}

The discussion focuses on the analyses of changes in mean climate over southern South America using the MM5 regional model by the end of the 21 st century (2080-2099), relative to 1970-1989 for summer (DJF), autumn (MAM), winter (JJA) and spring (SON).

\subsubsection{Spatial distribution}

\subsubsection{Changes in precipitation}

Left column in Figure 4 shows the spatial distribution of projected changes in seasonal precipitation over southern South America. Projected precipitation changes are positive or negative depending on the season and the region analyzed. The statistical significance of changes is addressed by means of a Student's $t$-test at a $95 \%$ confidence level and is also drawn in the figure with blue and red contours for positive and negative changes, respectively.
During summer, the figure shows a decrease in precipitation over southern Chile, Patagonia and the Bolivian Plateau. Furthermore, a strong precipitation increase is projected over the centre of Argentina and southern Brazil, Paraguay and western Bolivia. This precipitation increase is mainly due to the increase of the cyclonic circulation known as Chaco Low, which together with the southern displacement of the Atlantic Subtropical Anticyclone (Camilloni, 2005; Di Luca et al., 2006) results in a stronger moisture transport towards central Argentina. This pattern of change also agrees with results from the multi-model ensemble mean shown in Meehl et al. (2007) for the SRES A1B scenario. In addition, Soares and Marengo (2009), using the HadRM3P RCM have found an intensification of the Low Level Jet (LLJ), which would also explain the increased transport of moisture from the Amazonia into northern and central Argentina. Related to the study of statistical significance, it is worth noting that negative precipitation changes are statistically significant in southern Chile and the Bolivian Plateau, whereas positive precipitation changes are statistically significant in central Argentina, Uruguay-southern Brazil and subtropical latitudes. Those results are in agreement with Núñez et al. (2008).

Projected precipitation changes for MAM are similar to those for summer, although with somewhat smaller magnitude. Particularly, a precipitation decrease is apparent over central and southern Chile, the Bolivian Plateau, Argentinean Patagonia, and northern Argentina; whereas a rainfall increase is projected over central Argentina, Uruguay, southern Brazil and Paraguay. In general, these changes are not statistically significant at a 95\% confidence level. Only a few small regions were identified as statistically significant, which include positive changes in southern Brazil and negative changes in subtropical latitudes, central Chile and the Bolivian Plateau.

During winter, the projected changes are generally negative $\left(-0.5 \mathrm{~mm} \mathrm{day}^{-1}\right)$ over the entire domain, with a maximum precipitation decrease over central Chile. These changes are statistically significant at a $95 \%$ confidence level and are in agreement with Núñez et al. (2008). On the other hand, a slight precipitation increase is projected over southern of Chile as well as over central Argentina, southern Uruguay and mountainous regions between Chile, Bolivia and Argentina. Changes in the precipitation 

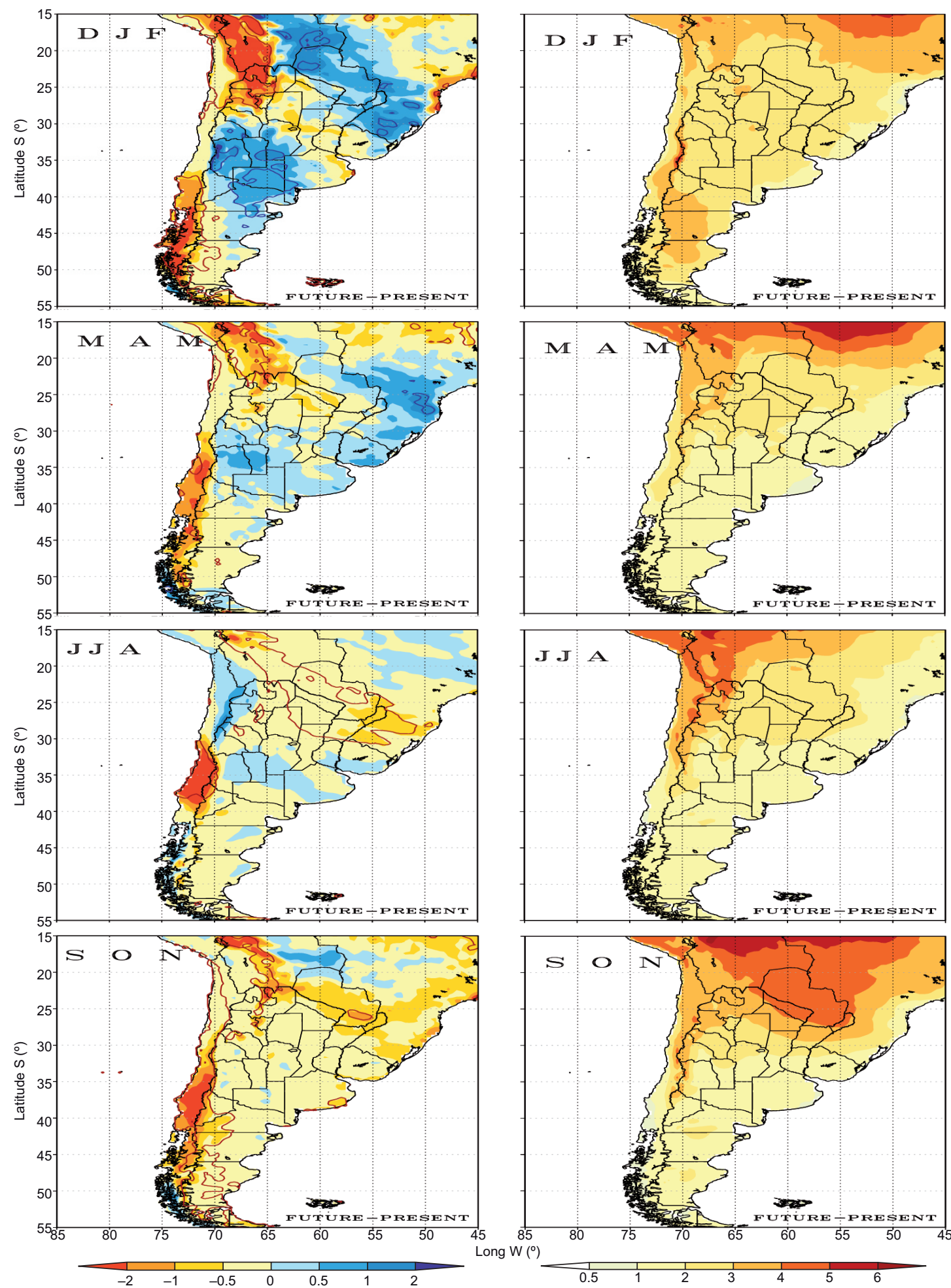

Fig. 4. Spatial distribution of simulated change in precipitation ( $\mathrm{mm} \mathrm{day}^{-1}$, left column) and temperature $\left({ }^{\circ} \mathrm{C}\right.$, right column) for summer (DJF), autumn (MAM), winter (JJA) and spring (SON), for the period 2080-2099 minus the period 1970-1989. Contoured regions indicate a 95\% confidence level. 
amount over Chile are consistent with the poleward expansion of the South Pacific subtropical high and the associated poleward shift of the Pacific Ocean storm-track, inducing a significant decrease in precipitation over central Chile and a precipitation increase over southern Chile and southern Argentina (Núñez et al., 2008). In subtropical latitudes, east of the Andes, the figure shows a general pattern of rainfall decrease with maximum precipitation decreased over eastern Argentina, southeastern Paraguay and southern Brazil. The pattern of precipitation change from the regional model agrees with the multi-model ensemble mean shown in Meehl et al. (2007) for the SRES A1B scenario.

In general, the model projects a rainfall decrease throughout the domain for spring. Particularly, a maximum rainfall decrease is found over central and southern Chile (around $-2 \mathrm{~mm} \mathrm{day}^{-1}$ ) and western Bolivia; whereas a slight rainfall increase is found over eastern Bolivia and northern Paraguay. However, only the precipitation decrease over central and southern Chile and western Bolivia is statistically significant.

Regardless of the season, a rainfall increase is projected over the eastern slope of the Andes (Argentina) and a rainfall decrease over the western slope of the Andes (Chile), particularly in mid-latitudes during summer and fall. In general, a precipitation increase is projected over central Argentina, Uruguay and southern Brazil, especially during summer and autumn; while a precipitation decrease is projected over Paraguay and south of Brazil during spring and over central Chile during winter and spring. Overall, projected precipitation changes seem to occur more likely in summer than in winter. In general, projected changes for summer and winter are in agreement with other studies from different RCMs and scenarios (Núñez et al., 2008; Cabré et al., 2010; Marengo et al., 2010; Krüger et al., 2012; Reboita et al., 2014; Sánchez et al., 2015). Besides, the simulated pattern of precipitation change is also similar to seasonal precipitation change from global climate models under SRES A2 (Torres and Marengo, 2013). Moreover, Chou et al. (2014) have found similar patterns of precipitation changes under the RCP 8.5 scenario based on the Eta RCM forced by two GCMs, the HadGEM2-ES and the MIROC5. For example, during summer a rainfall increase is projected over central Argentina, while a rainfall decrease is estimated over southern
Brazil. In winter, the pattern of precipitation change under SRES A2 is similar to the RCP 8.5 at the end of the century. In general, the pattern of change is well represented and differs only slightly in magnitude. In addition, the Argentinean Third National Communication on Climate Change (SAYDS, 2014) to the United Nations Framework Convention on Climate Change (UNFCCC) has been assessed using climatic scenarios RCP 4.5 and RCP 8.5 from the CMIP5 (Taylor et al., 2012) and climatic scenarios SRES A1B from the CMIP3 (Meehl et al., 2007a). Especially, according to the ensemble mean of 42 models from the CMIP5, the mean precipitation change relative to $1981-2005$ is a decrease of approximately 10 to $20 \%$ over northern and central Patagonia and a similar increase over central Argentina and most of the country, by 2075-2079 under RCP 8.5. Similar results were obtained in this study under the SRES A2 scenario. Furthermore, the statistical significance of results is in agreement with other studies from regional and global models (Núñez et al., 2008; Blázquez et al., 2012) under SRES A2 and SRES A1B.

\subsubsection{Changes in mean temperature}

Spatial distribution of the projected seasonal changes for surface air temperature by the end of the $21 \mathrm{st}$ century (2080-2099) is displayed in Figure 4 (right column). The increase in surface air temperature is of the order of 1.5 and $5.5{ }^{\circ} \mathrm{C}$ over southern South America by the end of the 21 st century. In addition, warming is around 2.5 to $5.5^{\circ} \mathrm{C}$ over tropical and subtropical latitudes, and does not exceed $3{ }^{\circ} \mathrm{C}$ south of $40^{\circ} \mathrm{S}$. Particularly, the maximum temperature increase (between 4 and $5^{\circ} \mathrm{C}$ ) occurs generally in spring over tropical and subtropical regions and over Argentinean Patagonia during summer $\left(3^{\circ} \mathrm{C}\right)$.

During austral summer the model projects a temperature increase of around $3.5^{\circ} \mathrm{C}$ over subtropical areas, $3^{\circ} \mathrm{C}$ over Argentinean Patagonia, and a maximum warming $\left(4.5^{\circ} \mathrm{C}\right)$ over subtropical latitudes. In winter, the regional model MM5 projects a temperature increase of around $2.5^{\circ} \mathrm{C}$ over Paraguay and northern Argentina (similar magnitudes were obtained for summer and fall) and greater than $4{ }^{\circ} \mathrm{C}$ over the Andean region between 15 and $30^{\circ} \mathrm{S}$. The projected maximum warming over the Andean region is also simulated by PRECIS RCM (CONAMA, 2006) under SRES A2 and by RegCM3 RCM (Reboita et 
al., 2014), MRI/JMA GCM (Blázquez et al., 2012) and by an ensemble of RCMs (Sánchez et al., 2015) under SRES A1B. Even though the projected temperature increase over southern South America depends on the season and the examined area, it should be noted that the largest warming is generally found over tropical and subtropical latitudes in spring and over the Andes during winter and spring.

For summer and winter, similar patterns of warming were found by Núñez et al. (2008) using the MM5 RCM, Krüger et al. (2012) using the RegCM3 RCM, Marengo et al. (2010) using the RegCM3, Eta CCS and HadRM3P models, Marengo et al. (2011) using the Eta/CPTEC model, Reboita et al. (2014) using RegCM3, and Sánchez et al. (2015) using an ensemble of RCMs. Note a reduction of $2{ }^{\circ} \mathrm{C}$ in the rise of temperature over southern Brazil, Paraguay, Bolivia and northern Argentina during JJA, compared to Núñez et al. (2008) under the same scenario. Moreover, warming has decreased about $1{ }^{\circ} \mathrm{C}$ during DJF. Therefore, this simulation of climate change has greatly improved the spatial distribution of temperature change, reducing the magnitude of projected warming.

According to Torres and Marengo (2013), all of the CMIP3 models project a temperature increase in all of South America that is more intense in its tropical portion and by the end of the century in higher emission scenarios (SRES A1B and SRES A2). For the South American continent as a whole, the range of temperature change is between 2 and $5{ }^{\circ} \mathrm{C}$ for the SRES A2 emission scenario. Similar results can be found in Meehl et al. (2007b). Moreover, Chou et al. (2014) have found similar temperature changes under the RCP 8.5 scenario based on the Eta RCM forced by two GCMs, the HadGEM2-ES and the MIROC5. For example, in summer the projected warming is around 2.5 to $5{ }^{\circ} \mathrm{C}$ over central Argentina and around 3 to $3.5^{\circ} \mathrm{C}$ over Patagonia. Whereas in winter the pattern of temperature increase is similar to SRES A2, the magnitude of temperature changes under RCP 8.5 is slightly lower than the previous one. In addition, the results from the Argentinean Third National Communication on Climate Change (SAYDS, 2014) to the UNFCCC project a temperature increase for the rest of the century over Argentina, and as it was expected the RCP 8.5 predicts the highest warming. Especially, according to the ensemble mean of 42 CMIP5 models, the mean temperature change relative to 1981-2005 could reach around 2.5 to $5{ }^{\circ} \mathrm{C}$ over Argentina by the end of the century. Regarding the statistical significance of mean temperature changes, a conventional $t$-test at a $95 \%$ confidence level was also performed (not shown in the right column of Figure 4). Therefore, the stated changes are statistically significant for all seasons and over the entire domain. Results are in agreement with other studies (Nuñez et al., 2008; Blázquez et al., 2012, among others) for SRES A2 and SRES A1B.

\subsection{Projected annual cycle}

\subsubsection{Precipitation}

Figure 5 shows the sub-regions selected for evaluating the annual cycle of precipitation. These regions were chosen particularly due to differences in their precipitation regimes, and most of them were defined by Solman et al. (2007). Figure 6 shows the annual cycle of monthly precipitation for present (1970-1989) and future climate (2080-2099) under the SRES A2 scenario (left column) and projected precipitation changes (right column) from the MM5 regional model for the sub-regions defined in Figure 5.

There are large seasonal and geographical variations in the changes of the annual cycle of precipitation, as can be seen in Figure 6. An increase in monthly precipitation is projected from April to November (highest in November [around 30\%]), except in October; while the opposite behavior occurs from December to March (highest in March [around 40\%]) over the southern Andes (SA). For Subtropical Andes (SUA), a rainfall decrease is projected from March to October (around 50\%), except in June. The greatest rainfall decrease is projected during the rainy season. Over the Paraguay (PA) region, wetter conditions are projected throughout the year, except for August, September and October. Over Cuyo (CU), the mean precipitation increases (between 80 and 100\%) occur during the first half of the year, and this behavior is reversed during the second half of the year (with a maximum deficit in precipitation of around $60 \%$ in September).

A maximum decrease in precipitation is projected during September (70\%) and a significant increase in June (150\%) over the southeast Pampas (SEP). Over the La Plata basin (LPB) region a subtle reduction of precipitation is projected during January, March, April, August, September, November and December, 


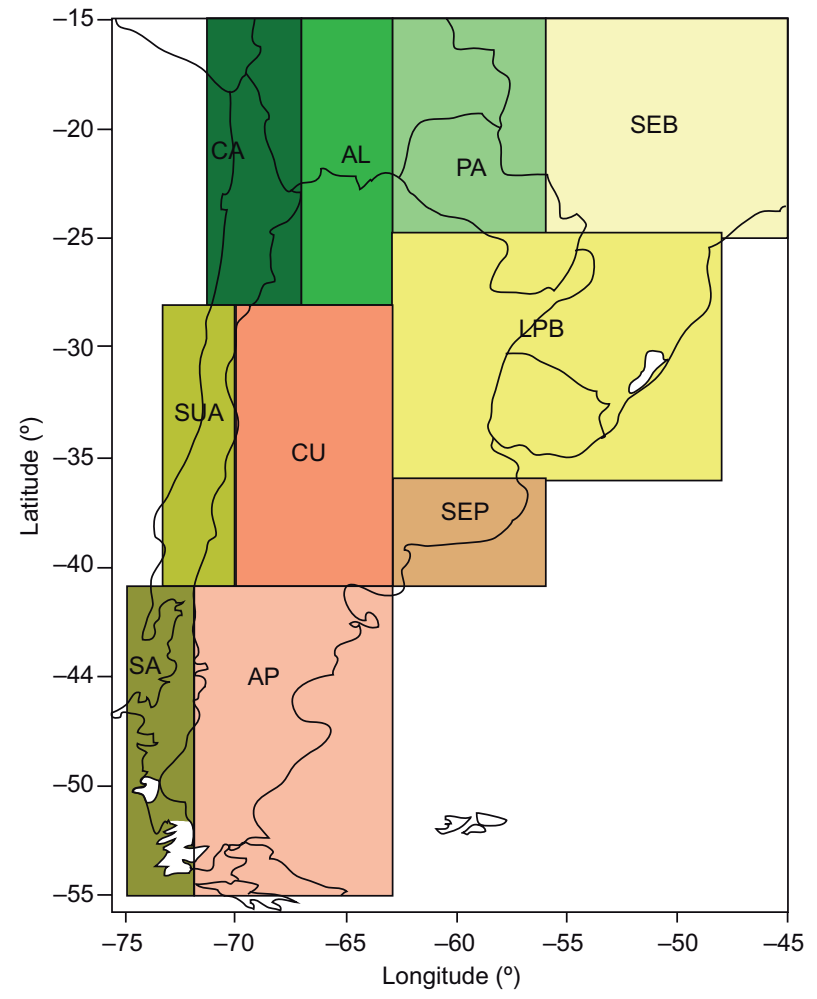

Fig. 5. Sub-regions used for a more detailed analysis of the annual cycle of precipitation: Andes centrales (CA), Altiplano (AL), Paraguay (PA), southeastern Brazil (SEB), subtropical Andes (SUA), Cuyo (CU), La Plata basin (LPB), south-eastern Pampas (SEP), southern Andes (SA), and Argentinean Patagonia (AP).

with increases during February, May, June, July and October. The greatest increase/decrease is found in June/September, around 40 and $60 \%$, respectively. Similar results were obtained by Marengo et al. (2009). Over the southeastern Brazil (SEB) region, wetter conditions are projected from March to July and dryer conditions from August to February. Projected changes for the annual cycle of precipitation by the end of the 21 st century predict a general rainfall decrease throughout the year, except on winter over the SEB and LPB regions. The maximum deficit is estimated during spring, while a smaller deficit is estimated during fall. Moreover, regions located to the east of the study domain (SEB, LPB, SEP) show an increase in the amplitude of the annual cycle of precipitation during winter and a decrease from spring to autumn.

Over the central Andes (CA) and Altiplano (AL), the regional MM5 model projects a monthly precipitation decrease (on average of 50\%) throughout the year, except for winter. For example, a maximum increase of $70 \%$ is projected in June over the CA region. Similar results were obtained by Urrutia and Vuille (2009) under SRES A2 and B2 from PRECIS RCM, and recently by Chou et al. (2014) under RCP 8.5, based on the Eta RCM. Broadly speaking, the results obtained are in agreement with previous studies (Nuñez et al., 2008; Marengo et al., 2009; Krüger et al., 2012, among others).

Figure 7 displays a schematic graph of seasonal projected changes in precipitation for the subregions defined in Figure 5.

\subsubsection{Mean temperature}

Figure 8 shows the selected subregions for evaluating changes in the annual cycle of temperature. These regions were defined in Solman et al. (2007). The choice of these subregions was motivated by the analysis of the projected climate change documented in Núñez et al. (2008). Figure 9 displays the annual cycle of monthly temperature for present climate (1970-1989) and future climate (2080-2099) under the SRES A2 scenario (left column), and projected temperature changes (right column) from the MM5 RCM for subregions defined in Figure 8.

The projected warming is present throughout the year, however, the maximum increase in temperature is found during autumn and spring in all the analyzed regions, except over the Andes (AN) and Patagonia (PAT).

Over southeastern South America (SESA), temperature increase is lower than $1.5{ }^{\circ} \mathrm{C}$ during the first half of the year, while it is between 1.5 and $3{ }^{\circ} \mathrm{C}$ during the second half of the year. In particular, Marengo et al. (2009) show a pronounced temperature increase during spring and summer $\left(4^{\circ} \mathrm{C}\right)$ with a strong difference in amplitude between winter and summer in regions located over subtropical latitudes. Significant warming over the SESA region during spring under the SRES A2 scenario is in agreement with the results of Núñez et al. (2008). Therefore, the projected warming simulated here is of lower magnitude. From this it can be inferred that projections of the present regional climate change show greater consistency with other regional model temperature projections over the SESA region. The magnitude of the projected warming $\left(4{ }^{\circ} \mathrm{C}\right)$ throughout the year over the SESA and Subtropical (ST) regions is also documented by other authors (Marengo et al., 2010; 

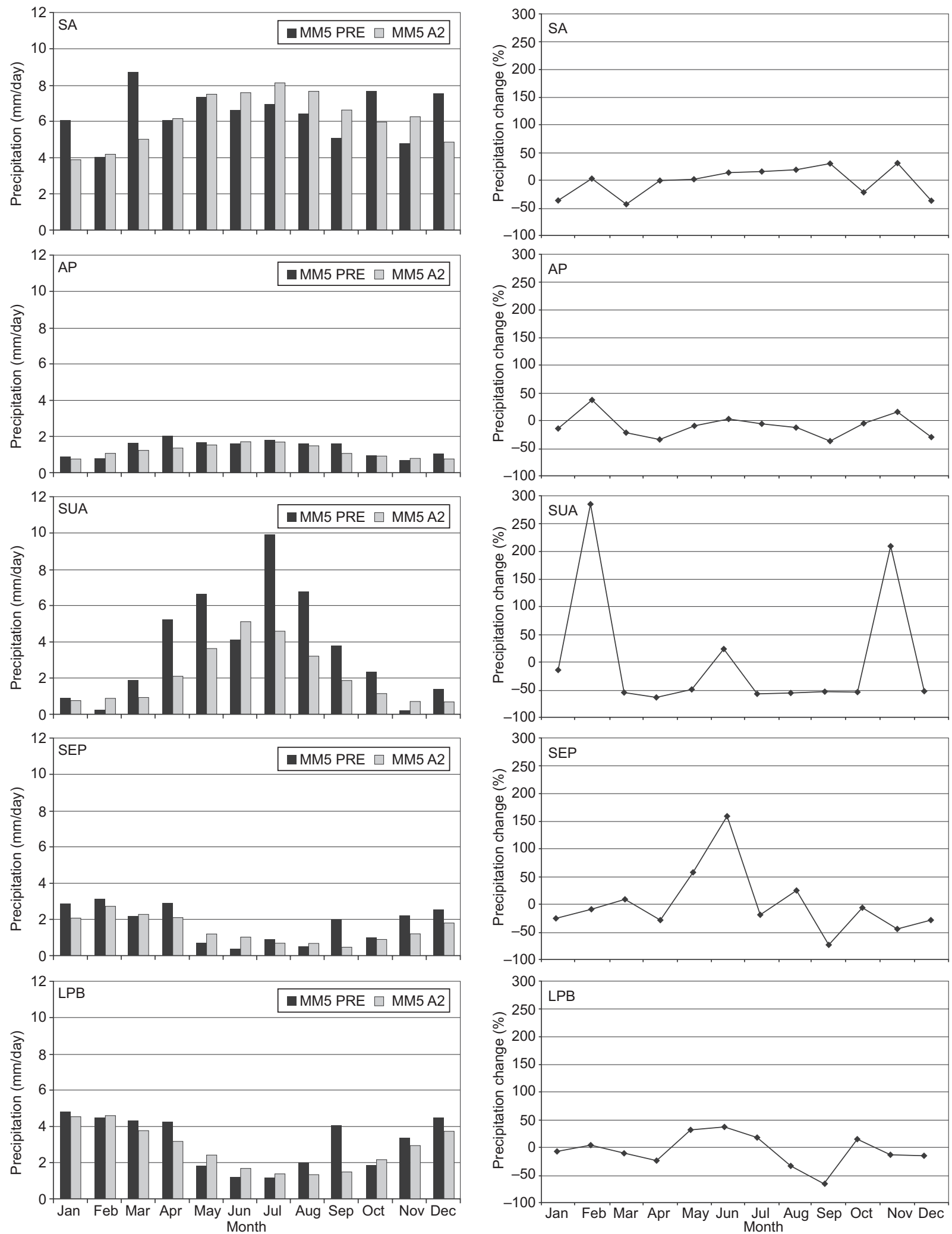

Fig. 6. Left column: Annual cycle of the monthly mean precipitation for present ( $\mathrm{mm} \mathrm{day}^{-1}$, dark bars) and future climate (light grey bars). Right column: Projected precipitation changes (\%). Subregions were defined in Figure 5. (Continues.) 

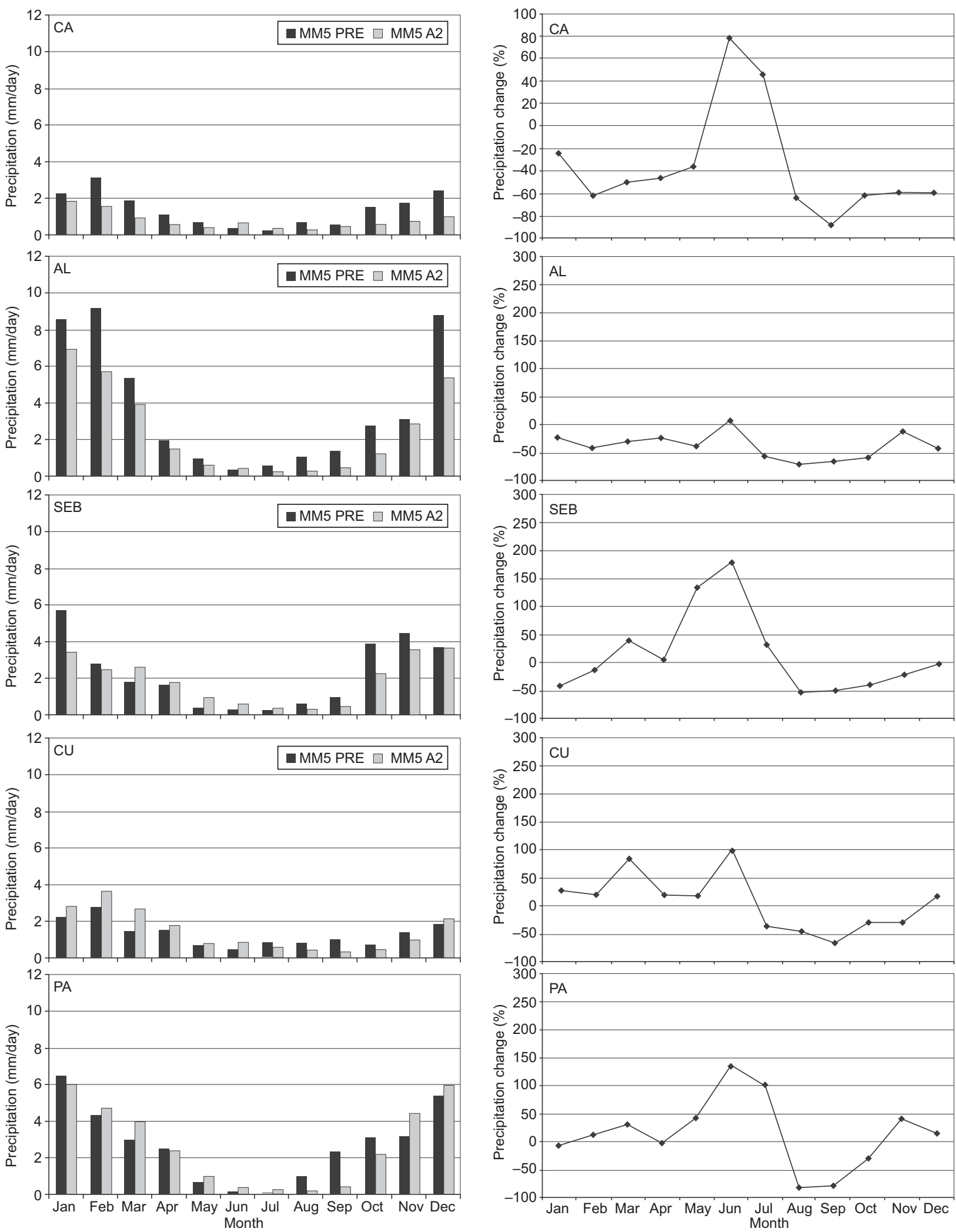

Fig. 6. (Continued.) 


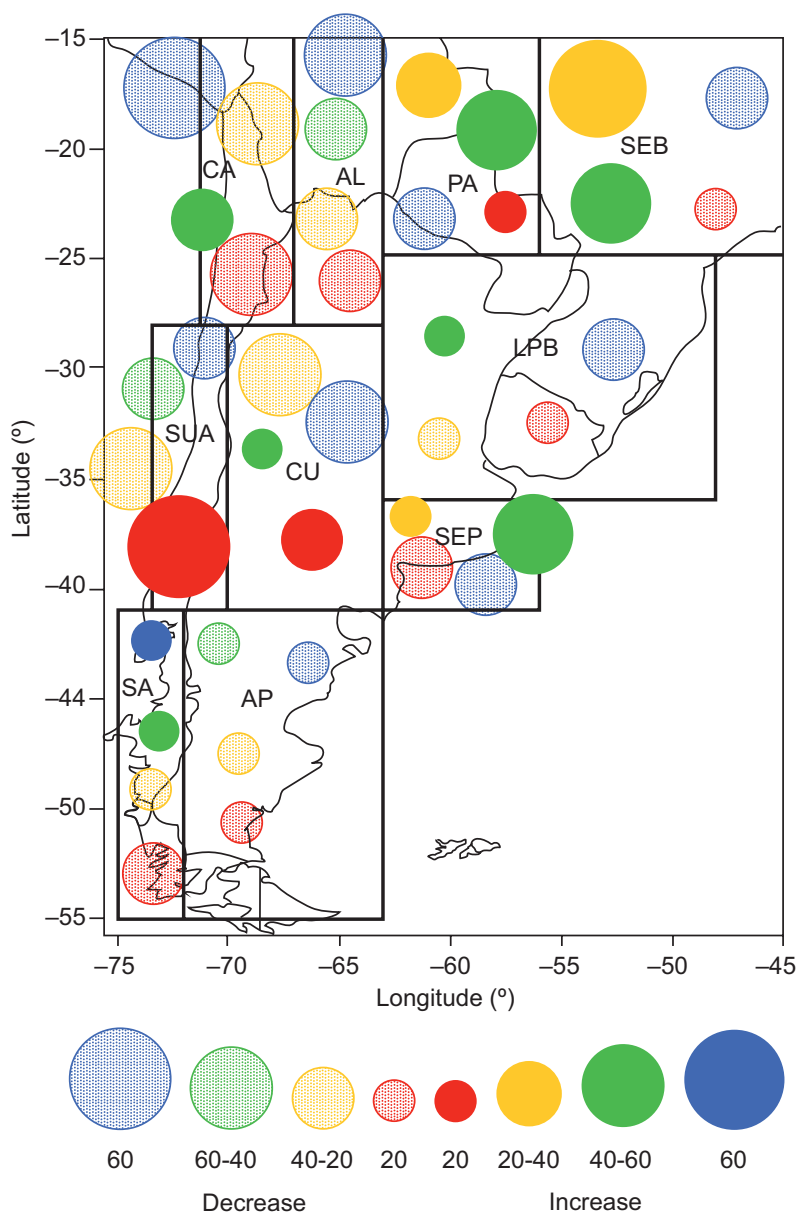

Fig. 7. Schematic graph of the MM5 seasonal projected changes (\%) in the subregions defined in Figure 6 (red: DJF; orenge: MAM; green: JJA; blue: SON). The size of the circles indicates the magnitude of the overestimation (solid circles) and underestimation (dot circles)

Krüger et al., 2012). Over the central Argentina (CARG) region, the MM5 RCM projects a maximum increase in temperature $\left(2-3{ }^{\circ} \mathrm{C}\right)$ for November and December. Over the ST region, maximum/minimum warming is found in September/June.

On the other hand, the AN and PAT regions show a different behavior compared to previous regions. Over PAT, the projected (maximum/minimum) temperature increase is found in February/May-June. The maximum warming (about $2.5^{\circ} \mathrm{C}$ ) in AN occurs during July and the minimum (about $2{ }^{\circ} \mathrm{C}$ ) in February. Similar results over AN are shown in Núñez et al. (2008), however the warming obtained here is of lower magnitude. Torres and Marengo (2013) have found similar results over the AN region under the SRES A2 emission scenario with 24 GCMs from the

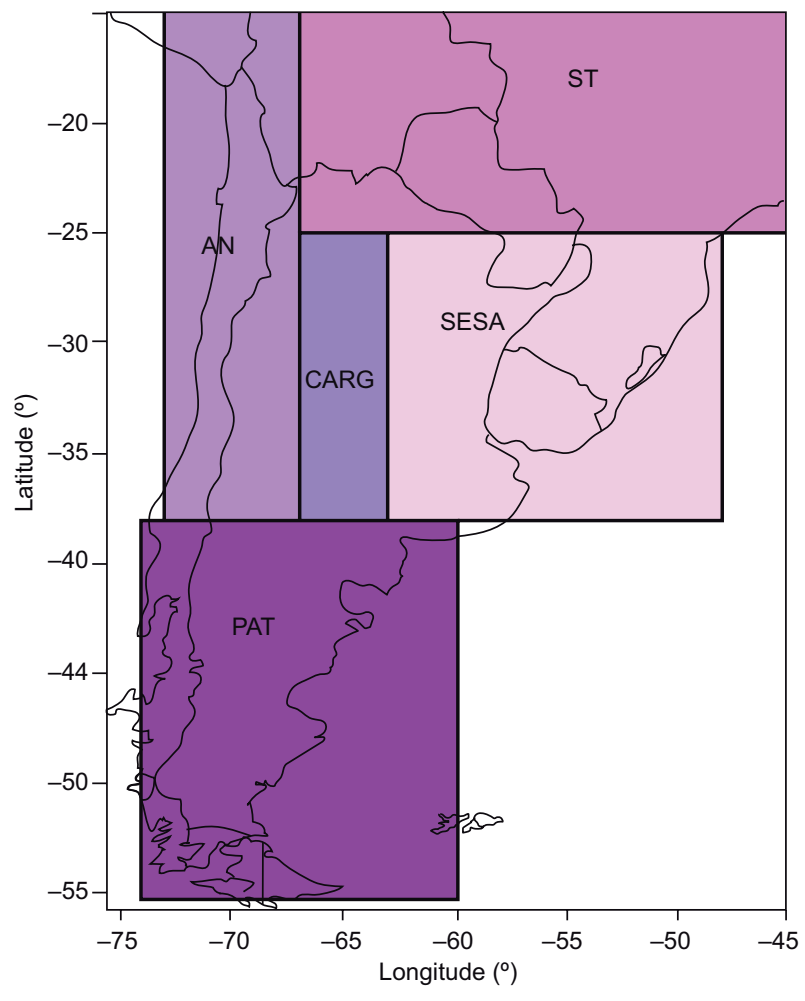

Fig. 8. Subregions defined for a more detailed analysis of the annual cycle of mean temperature. ST: subtropical; AN: Andes; CARG: Central Argentina; SESA: southeastern South America; PAT: Patagonia.

CMIP3 dataset (IPCC, 2007; Solomon et al., 2007). Particularly, as projected by the MM5 regional model, warming during winter and spring is higher compared to summer and autumn.

Regardless of the selected subregion, the projected warming is lower than $4.5^{\circ} \mathrm{C}$ in the late 21 st century. Particularly, a warming between 2 and $4.5^{\circ} \mathrm{C}$ is found over ST, between 1 and $3{ }^{\circ} \mathrm{C}$ over CARG, less than $2{ }^{\circ} \mathrm{C}$ over PAT, less than $3{ }^{\circ} \mathrm{C}$ over SESA, and $2-3^{\circ} \mathrm{C}$ over the $\mathrm{AN}$ regions. Furthermore, the largest warming is located over central-eastern Argentina, Uruguay, southern Brazil and the subtropical latitudes (ST, CARG and SESA) during autumn and spring, and with a lesser degree during winter. For example, the maximum rising temperature (around $4.5^{\circ} \mathrm{C}$ ) was found over ST during spring. Even though results discussed previously are in general agreement with Nuñez et al. (2008), the warming obtained here is of lower magnitude. Similar outcomes were also found by Blázquez et al. (2012) and Núñez and Blázquez (2014) from global climate models. As a final remark, in both in the late 21 st century and in the late 20 th 

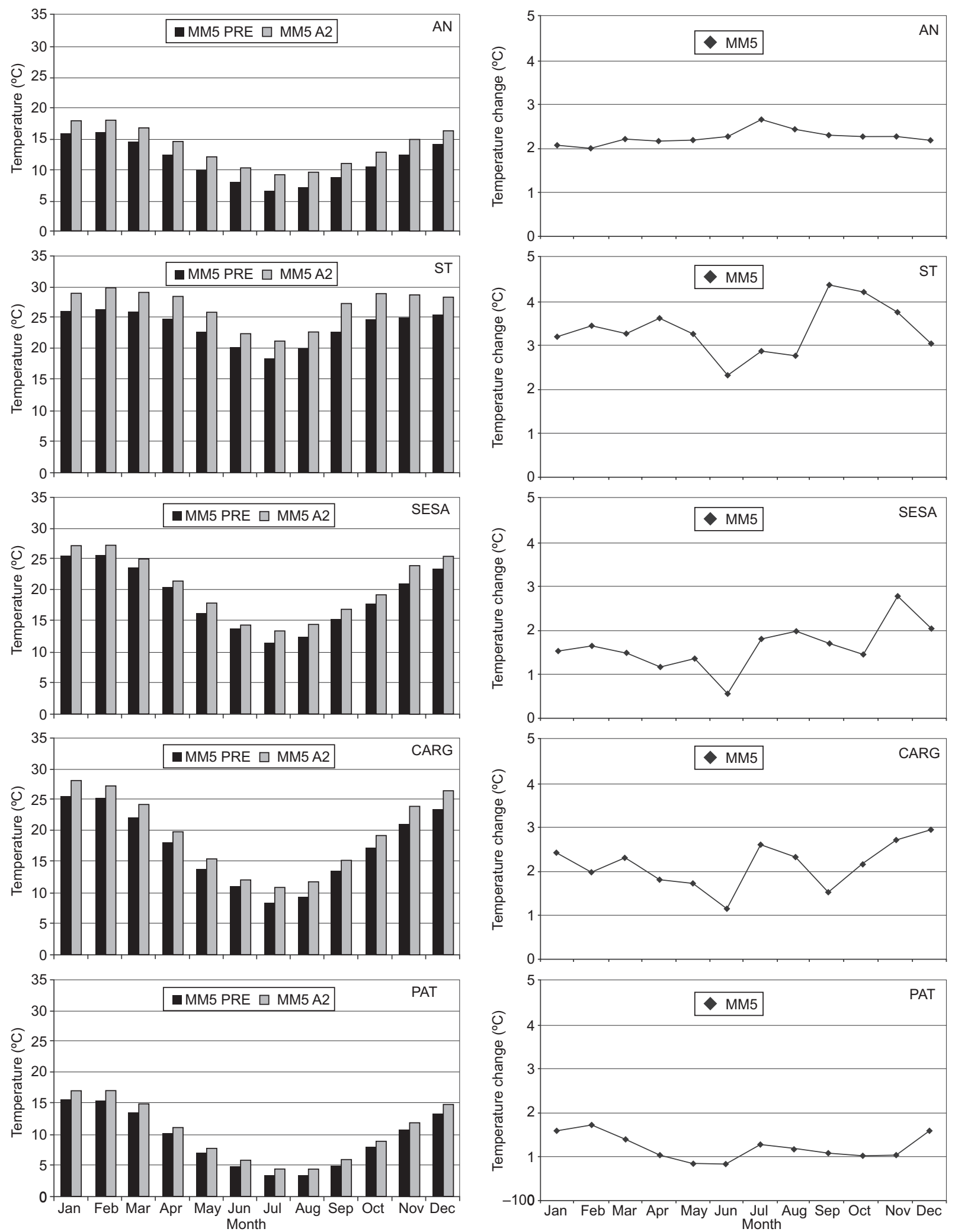

Fig. 9. Annual cycle of monthly mean temperature $\left({ }^{\circ} \mathrm{C}\right)$ for present and future climate (left column) and projected temperature changes (right column). Subregions were defined in Figure 8. 
century, the annual cycle of temperature is similar; the only difference is the higher temperature projected for future climate. Clearly, this has implications for the end of 21 st century.

Figure 10 displays a diagram of the seasonal projected temperature changes for subregions defined previously.

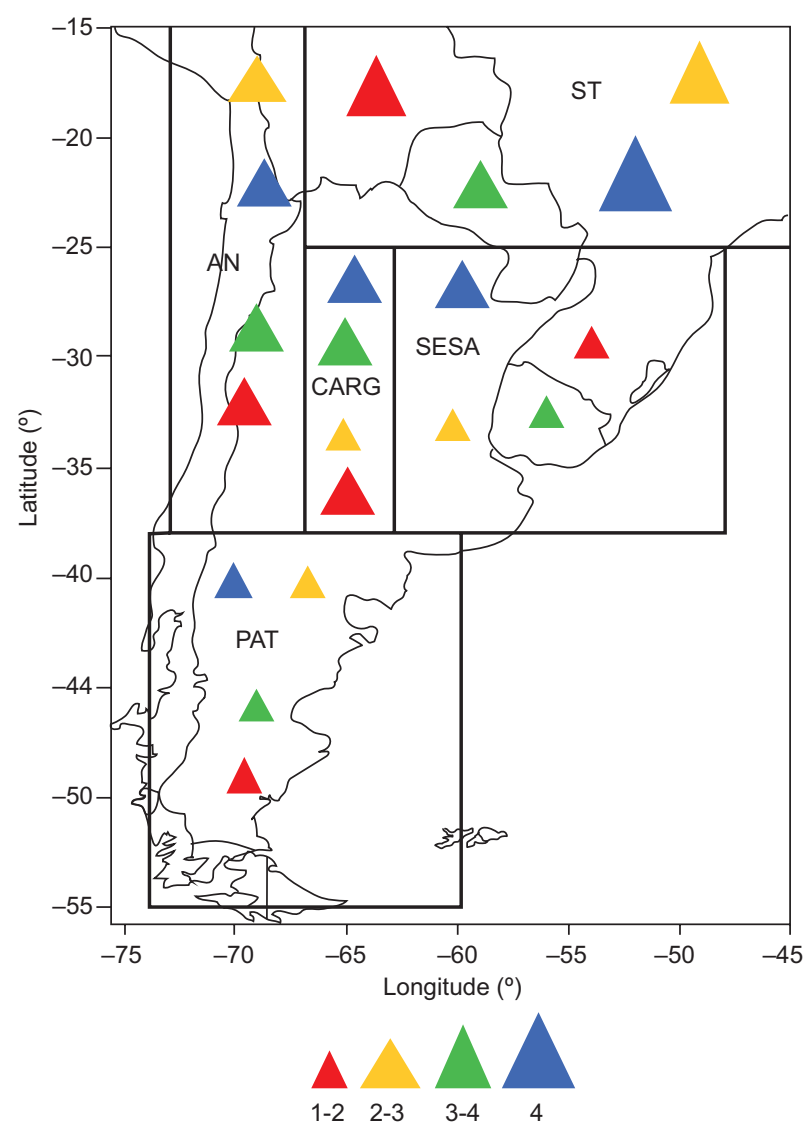

Fig. 10. Schematic graph of the MM5 seasonal projected changes $\left({ }^{\circ} \mathrm{C}\right)$ in the subregions defined in Figure 8. Red: DJF; orange: MAM; green: JJA; blue: SON. The size of the triangle indicates the magnitude of the temperature increase.

\subsection{Projected changes in interannual variability \\ 3.4.1 Spatial distribution}

The analysis of changes in the interannual variability of precipitation and temperature over southern South America is shown in Figures 11 and 12, respectively. Due to the way in which the scenario is constructed with the global model (where the interannual variability of SST corresponds to observed SST modified with an added linear trend), a very large change in interannual variability from the regional model is not expected. Therefore, regardless of the season, the spatial distribution of the interannual variability of precipitation and temperature for future climate is similar to current climate (1970-1989).

\subsubsection{Precipitation}

Figure 11 shows the spatial distribution of the interannual variability of precipitation as projected by the MM5 regional model, quantified in terms of the standard deviation (STDV) for future climate for DJF, MAM, JJA and SON (left column), and its differences from present climate (right column).

Changes in the interannual variability of precipitation are about $\pm 1 \mathrm{~mm}$ day $^{-1}$ throughout the study domain. In general, a slight increase in the interannual variability of precipitation is projected during summer, autumn and winter over central Argentina, Uruguay and the south of Brazil. However, larger negative changes ( 1 to $3 \mathrm{~mm} \mathrm{day}^{-1}$ ) in interannual variability are apparent during autumn, winter and spring over central Chile.

In summer, the model projects two areas of increase in the interannual variability of precipitation. One is located over central-western Argentina and the other over southern Brazil, Uruguay, eastern Argentina and southwestern Bolivia. Values of around 1 to $2 \mathrm{~mm} \mathrm{day}^{-1}$ are found in small areas located over northern Uruguay and western-central Argentina.

In winter, a decrease in the interannual variability of precipitation is projected over most of the domain, with areas below $1 \mathrm{~mm}^{-1 a y}{ }^{-1}$ over northern Argentina, Paraguay and Bolivia, as well as over the Argentinean Patagonia, and values between 1 and $2 \mathrm{~mm}_{\text {day }}{ }^{-1}$ over central and southern Chile. An opposite pattern is projected over subtropical latitudes in eastern Brazil, Argentina and the border region of Chile, Argentina and Bolivia (reaching peaks of around 2-3 $\mathrm{mm} \mathrm{day}^{-1}$ ).

\subsubsection{Mean temperature}

Figure 12 shows the spatial distribution of the interannual variability of temperature for the late 21 st century under the SRES A2 scenario (left column) and its difference from the current climate (right column). Regardless of the season, the spatial distribution of the projected interannual variability of temperature, basically shows a similar pattern as current climate (1970-1989). In general, a decrease in the interannual variability of temperature is projected over central 

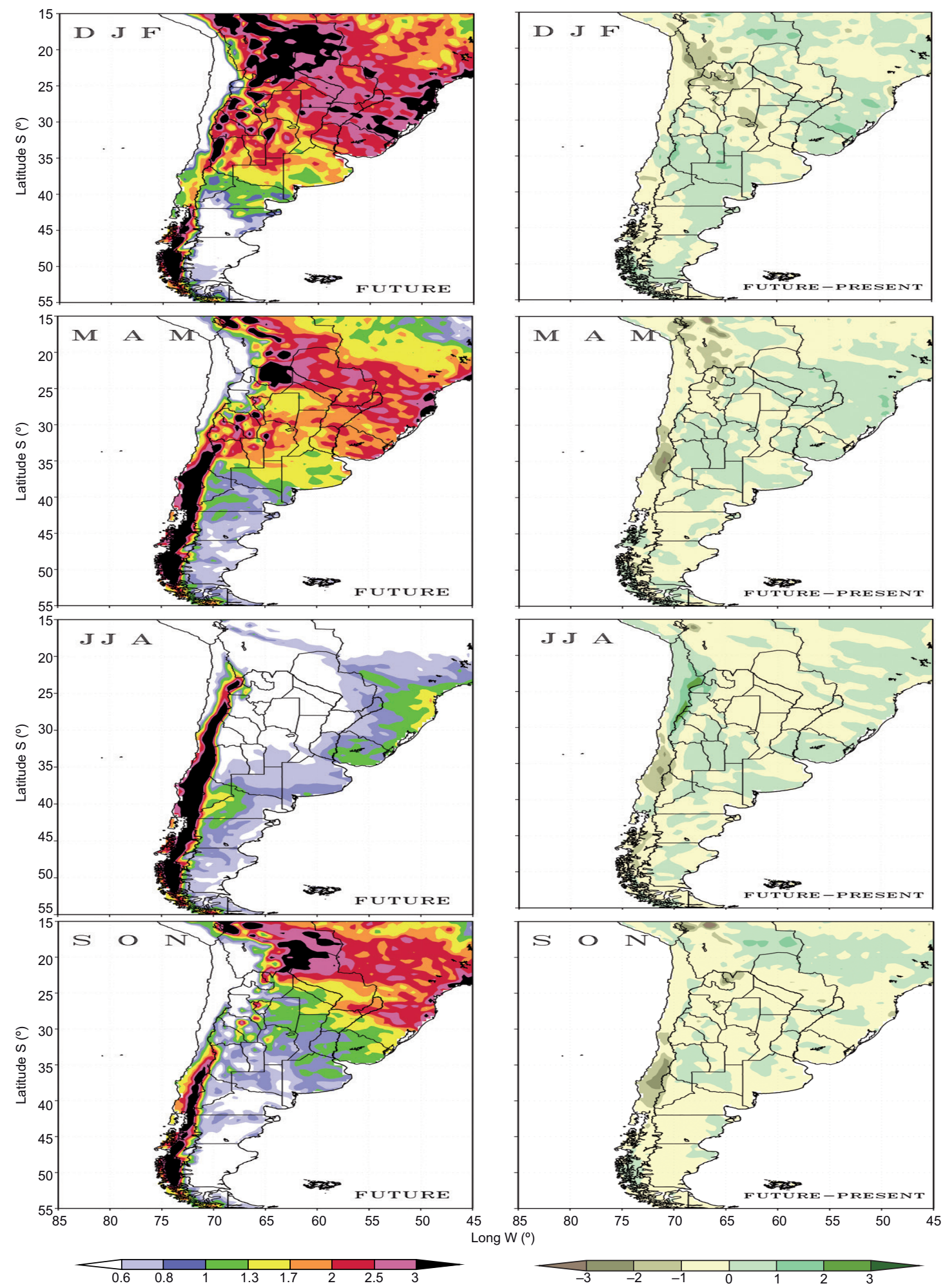

Fig. 11. Spatial distribution of the standard deviation $\left(\mathrm{mm} \mathrm{d}^{-1}\right)$ for simulated precipitation for DJF, MAM, JJA, SON for future climate (left column) and changes related to present climate, difference between future and present climate periods (right column). 

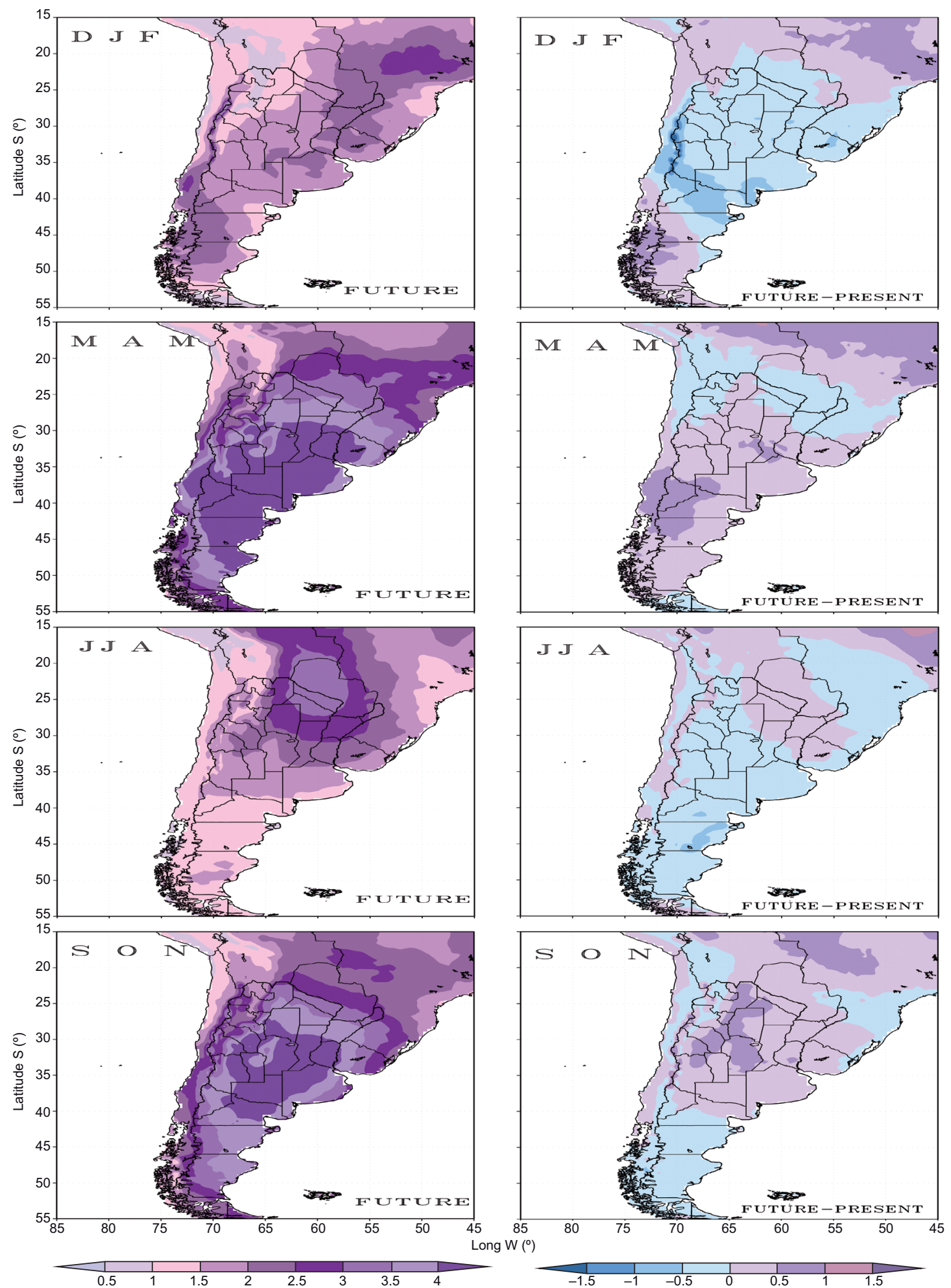

Fig. 12. Spatial distribution of the standard deviation $\left({ }^{\circ} \mathrm{C}\right)$ for simulated temperature for DJF, MAM, JJA and SON for future climate (left column) and changes related to present climate, difference between future and present periods (right column). 
and northern Argentina and Uruguay for summer and winter, while the opposite pattern is projected for autumn and spring.

During summer, a slight decrease of the interannual variability of temperature (around $0.5^{\circ} \mathrm{C}$ ) is projected over central and northern Argentina and Uruguay, with a maximum decrease projected over the north of the Argentinean Patagonia and central Chile. A small increase of the interannual variability of temperature (about $0.5^{\circ} \mathrm{C}$ ) over the south of the Argentinean Patagonia is apparent and another maximum increase (about $1^{\circ} \mathrm{C}$ ) is also apparent over the southwest tip of the continent. Moreover, another area of maximum interannual variability of temperature is projected over subtropical latitudes, with values not exceeding $1^{\circ} \mathrm{C}$.

In winter, the regional model MM5 projects a slight decrease in the interannual variability of temperature over central Argentina, southern Brazil, southern Chile and the Argentinean Patagonia; whereas a slight increase in the interannual variability of temperature (around $0.5{ }^{\circ} \mathrm{C}$ ) is projected over northeastern Argentina, Paraguay, Uruguay and southern Bolivia.

In brief, a slight decrease in the interannual variability of temperature is projected for summer and winter over a large extent of Argentina. On the other hand, the MM5 model projects a slight increase in the interannual variability of temperature over central Argentina and the subtropical latitudes during transition seasons. The highest increases in interannual variability (around $1{ }^{\circ} \mathrm{C}$ ) are found over central Chile during fall and over north central Argentina during spring.

Similar results concerning future changes in the interannual variability of precipitation and temperature were found over South America from GCMs by Giorgi and Bi (2005a, b); Giorgi and Diffengaubh (2008); Blázquez et al., (2012), among others.

\section{Summary and conclusions}

Results reported here were based on one realization of the MM5 RCM forced by a single driving HadAM3H GCM. The analysis was focused on evaluating the spatial distribution of seasonal temperature and precipitation changes in terms of: (i) mean climate, (ii) interannual variability and (iii) the annual cycle of monthly temperature and precipitation changes for selected subregions. In addition, in order to discuss the climate model robustness, a brief evaluation of uncertainties in regional model projections was also included. It has been found that the MM5 model agrees with high-resolution global projections and other regional projections, suggesting that it is an efficient tool to generate high-resolution scenarios of climate change over southern South America. Main conclusions can be summarized as follows:

1. The projected precipitation changes are positive or negative depending on the season and the region analyzed. A rainfall increase is projected over central Argentina, Uruguay and southern Brazil, especially during summer; whereas highest negative values are found over the Bolivian Plateau and southern Chile. The highest negative changes were found over central Chile in winter. In autumn, negative changes were found over southern and central Chile and highest positive changes were found over southern Brazil, Uruguay and central Argentina. For spring, the MM5 model projects a precipitation decrease over most of the study domain, however highest negative values were found at central and southern Chile. The statistical analyses conclude that projected precipitation changes conclude that variations in precipitation are significant (95\% of confidence level) during summer over southern and central Chile; during winter over northern Argentina, Paraguay and southern Brazil, and central Argentina; whereas projected precipitation changes for intermediate seasons are not statistically significant over the whole study domain, except for spring over central and southern Chile.

2. The projected temperature increase over southern South America depends on the season and the examined area. Particularly, it ranges from 1.5 to $5.5^{\circ} \mathrm{C}$, being highest over subtropical latitudes. Seasonally, the warming is greatest during spring. The regional model projects a maximum temperature increase (between 4 and $5{ }^{\circ} \mathrm{C}$ ) over tropical and subtropical latitudes mainly during spring, and a large warming $\left(3{ }^{\circ} \mathrm{C}\right)$ over high latitudes (south of $40^{\circ} \mathrm{S}$ ) during summer. Warming found over northeastern Argentina and Paraguay is similar for winter, summer and autumn, and it is greatest during spring. Regarding temperature, the projected changes are statistically 
significant in all seasons (at a 95\% confidence level) throughout the domain considered.

3. Concerning the projected annual cycle of precipitation, the MM5 model projects a rainfall increase (20-60\%) during winter and spring, regardless of the selected region. Moreover, a precipitation decrease (lower than 60\%) is projected for summer and autumn. A strong precipitation increase (higher than $60 \%$ ) is projected during summer over SUA and during autumn over SEB. In general, a precipitation increase (above 60\%) is projected over SUA during summer; over SEB during autumn, and over CA during spring. Concerning temperature, regardless of the selected region, a warming between 3 and $4{ }^{\circ} \mathrm{C}$ is projected for summer, winter and spring. The maximum warming (higher than $4{ }^{\circ} \mathrm{C}$ ) is projected over the ST region during spring.

4. Regardless of the season, the MM5 RCM projects a low increase in the interannual variability of precipitation by the end of the 21 st century under the SRES A2 scenario, compared to current climate. However, some seasonal characteristics are worth noting. A slight increase in the interannual variability of precipitation is projected over central Argentina and Uruguay for summer and winter. Especially for temperature, a slight decrease in the interannual variability is projected for summer and winter over a large extent of Argentina. However, the MM5 model projects a slight increase in the interannual variability of temperature during transition seasons, with highest values over central Chile in MAM and north central Argentina in SON.

5. The assessment of uncertainty in climate change projections revealed that temperature is a more reliable parameter than precipitation over southern South America by the end of the 21 st century. Regardless the season, temperature projections are reliable over the entire study domain, particularly in subtropical latitudes, whereas the level of reliability for temperature projections over Uruguay-southern Brazil and east-central Argentina depends on seasonality. On the other hand, regardless the season projections of precipitation show less reliability in all evaluated areas. Hence, results obtained represent an important contribution to the characterization of uncertainty and reliability of regional climate simulations over southern South America. To conclude, in spite of the different levels of reliability found for temperature and precipitation changes, the MM5 RCM can indeed provide valuable information for preliminary assessment of impact studies.

\section{Acknowledgments}

We would like to thank the Hadley Centre for providing the HadAM3H data. This work was supported by CONICET Grant PIP 112-201101-00189, UBACYT Grant Y028, FONCyT-PICT-2012-1972 and UBACYT2014 20020130200233BA. The authors wish to acknowledge two anonymous reviewers for very helpful suggestions which certainly led to an overall improvement of the paper.

\section{References}

Arnell N. W., D. A Hudson and R. G. Jones, 2003. Climate change scenarios from a regional model: Estimating change in runoff in southern Africa. J. Geophys. Res. 108, 4519, doi:10.1029/2002JD002782.

Beniston M., D. B. Stephenson, O. B. Christensen, C. A. T. Ferro, C. Frei, S. Goyette, K. Halsnaes, T. Holt, K. Jylhä, B. Koffi, J. Palutikof, R. Schöll, T. Semmle and K. Woth, 2007. Future extreme events in European climate: An exploration of regional climate model projections. Climatic Change 81, 71-95, doi:10.1007/ s10584-006-9226-z.

Blázquez J., M. Núñez and S. Kusunoki, 2012. Climate projections and uncertainties over South America from MRI/JMA global model experiments. Atmospheric and Climate Sciences, doi:10.4236/acs.2012. Available at: http://www.scirp.org/journal/acs.

Blázquez J. and M. Núñez, 2012a. Performance of a high resolution global model over southern South America. Int. J. Climatol., doi:10.1002/joc.3478.

Blázquez J. and M. Núñez, 2012b. Analysis of uncertainties in future climate projections for South America: Comparison of WCRP-CMIP3 and WCRP-CMIP5 models. Clim. Dynam., doi:10.1007/s00382-0121489-7.

Branković Č., M. Patarčić, I. Güttler and L. Srnec, 2012. Near-future climate change over Europe with focus on Croatia in an ensemble of regional climate model simulations. Clim. Res. 52, 227-251, doi:10.3354/cr01058.

Buytaert W., R. Celleri and L. Timbe, 2009. Predicting climate change impacts on water resources in the tropical Andes: Effects of GCM uncertainty. Geophys. Res. Lett. 36, L07406. 
Cabré M. F., S. A. Solman and M. N. Núñez, 2010. Creating regional climate change scenarios over southern South America for the 2020's and 2050's using the pattern scaling technique: Validity and limitations. Climatic Change. 98, 449-469, doi:10.1007/s10584009-9737-5.

Cabré M. F., S. A. Solman and M. N. Núñez, 2014. Climate downscaling over southern South America for present-day climate (1970-1989) using the MM5 model. Mean, interannual variability and internal variability. Atmósfera 27, 117-140

Camilloni I., 2005. Tendencias climáticas. In: El cambio climático en el Río de la Plata (V. A. G. ). CIMA, Buenos Aires, 200 pp.

Cavalcanti I. and M. Shimizu, 2012. Climate fields over South America and variability of SACZ and PSA in HadGEM2-ES. American Journal of Climate Change 1, 132-144, doi:10.4236/ajcc.2012.13011.

Chen F. and J. Dudhia, 2001. Coupling and advanced land surface-hydrology model with the Penn State-NCAR MM5 modeling system. Pat I. Model implementation and sensitivity. Mon. Weather Rev. 129, 569-585.

Chotamonsak C., E. P. Salathé Jr., J. Kreasuwan, S. Chantara and K. Siriwitayakorn, 2011. Projected climate change over Southeast Asia simulated using a WRF regional climate model Atmos. Sci. Lett., doi:10.1002/ asl.313.

Chou S. C., A. Lyra, C. Mourao, C. Dereczynski, I. Pilotto, J. Gomes, J. Bustamente, P. Tavares, A. Silva, D. Rodrigues, D. Campos, D. Chagas, G. Sueiro, G. Siqueira and J. Marengo, 2014. Assessment of climate change over South America under RCP 4.5 and 8.5 downscaling scenarios. American Journal of Climate Change 3, 52887, doi:10.4236/ajcc.2014.35043.

Christensen O. B., 1999. Relaxation of soil variables in a regional climate model. Tellus 51A, 674-685.

Christensen O. B., M. A. Gaertner, J. A. Prego and J. Polcher, 2001. Internal variability of regional climate models. Clim. Dynam. 17, 875-887.

Christensen J. H., B. Hewitson, A. Busuioc, A. Chen, X. Gao, I. Held, R. Jones, R. K. Kolli, W.-T. Kwon, R. Laprise, V. Magaña, L. Mearns, C. G. Menéndez, J. Räisänen, A. Rinke, A. Sarr and P. Whetton, 2007a. Regional climate projections. In: Climate change 2007: The physical science basis. Contribution of Working Group I to the Fourth Assessment Report of the Intergovernmental Panel on Climate Change (S. Solomon, D. Qin, M. Manning, Z. Chen, M. Marquis, K. B. Averyt, M. Tignor and H. L. Miller, Eds.).
Cambridge University Press, Cambridge, United Kingdom and New York.

Christensen J. H., T. R. Carte, M. Rummulainen and G. Amanatidis, 2007b. Evaluating the performance and utility of regional climate models: The PRUDENCE project. Climatic Change 81, 1-6, doi:10.1007/s10584006-9211-6.

CONAMA, 2006. Variaciones climáticas en Chile para el siglo XXI: Informe final. Comisión Nacional del Medio Ambiente-Departamento de Geofísica, Facultad de Ciencias Físicas y Matemáticas, Universidad de Chile, 63 pp.

Deser C., A. Phillips, V. Bourdette Vincent and H. Teng Haiyan, 2012. Uncertainty in climate change projections: The role of internal variability. Clim. Dynam. 38, 527-546, doi:10.1007/s00382-010-0977-X.

Déqué M., R. G. Jones, M. Wild, F. Giorgi, J. H. Christensen, D. C. Hassell, P. L. Vidale, B. Rockel, D. Jacob, E. Kjellström, M. de. Castro, F. Kucharski and B. van den Hurk, 2005. Global high resolution versus Limited Area Model climate change projections over Europe: quantifying confidence level from PRUDENCE results. Clim. Dynam. 25, 653-670, doi:10.1007/s00382-0050052-1

Di Luca A., I. Camilloni and V. Barros, 2006. Sea-level pressure patterns in South America and the adjacent oceans in the IPCC AR4 models. Proceedings of the 8th International Conference on Southern Hemisphere Meteorology and Oceanography, Foz do Iguaçu, Brazil, 24-28 April, pp. 235-244.

Diniz Filho J. A. F., L. M. Bini, T. F. Rangel, R. D. Loyola, C. Hof, D. Nogués-Bravo and M. B. Araújo, 2009. Partitioning and mapping uncertainties in ensembles of forecasts of species turnover under climate change. Ecography 32, 897-906.

Doblas-Reyes F. J., R. Hagedorn and T. N. Palmer, 2005. The rationale behind the success of multi-model ensembles in seasonal forecasting - II. Calibration and combination. Tellus A 57, 234-252.

Flato G., J. Marotzke, B. Abiodun, P. Braconnot, S. Chou, W. Collins, P. Cox, F. Driouech, S. Emori, V. Eyring, C. Forest, P. Gleckler, E. Guilyardi, C. Jakob, V. Kattsov, C. Reason and M. Rummukainen, 2013. Evaluation of climate models. In: Climate change 2013: The physical science basis. Contribution of Working Group I to the Fifth Assessment Report of the Intergovernmental Panel on Climate Change (T. F. Stocker, D. Qin, G.-K. Plattner, M. Tignor, S. K. Allen, J. Boschung, A. Nauels, Y. Xia, V. Bex and P. M. Midgley, Eds.). 
Cambridge University Press, Cambridge, United Kingdom and New York, NY, USA.

Foley, 2010. Uncertainty in regional climate modelling: A review. Prog. Phys. Geog. 34, 647-670, doi:10.1177/0309133310375654.

Franchito S., J. Fernández and D. Pareja, 2014. Surrogate climate change scenario and projections with a regional climate model: Impact on the ARIDITY in South America. American Journal of Climate Change 3, 474-489, doi:10.4236/ajcc.2014.35041.

Gaertner M. A., J. M. Gutiérrez and M. Castro, 2012. Escenarios regionales de cambio climático. Revista Española de Física 26, 34-42. Disponible en: http:// www.meteo.unican.es/node/73102.

Gao X., J. S. Pal and F. Giorgi, 2006. Projected changes in mean and extreme precipitation over the Mediterranean region from a high resolution double nested RCM simulation. Geophys. Res. Lett. 33, L03706, doi:10.1029/2005GL024954.

Garrand L., 1983. Some improvements and complements to the infrared emissivity algorithm including a parameterization of the absorption in the continuum region. J. Atmos. Sci. 40, 230-244.

Garreau R. and M. Falvey, 2008. The coastal winds off western subtropical South America in future climate scenarios. Int. J. Climatol. 29, 543-554, doi:10.1002/ joc.1716.

Giorgi F. and R. Francisco, 2000. Uncertainties in regional climate change prediction: a regional analysis of ensemble simulations with the HADCM2 coupled AOGCM. Clim. Dynam. 16, 169-182, doi:10.1007/ PL00013733.

Giorgi F. and L. O. Mearns, 2002. Calculation of average, uncertainty range, and reliability of regional climate changes from AOGCM simulations via the "reliability ensemble averaging" (REA) method. J. Climate 15, 1141-1158.

Giorgi F., X. Bi and J. Pal 2004. Mean, interannual variability and trends in a regional climate change experiment over Europe. II: climate change scenarios (2071-2100). Clim. Dynam. 23, 839-858.

Giorgi F. and X. Bi, 2005a. Regional changes in surface climate interannual variability for the 21 st century from ensembles of global model simulations. Geophys. Res. Lett. 32, L13701.

Giorgi F. and X. Bi, 2005b. Updated regional precipitation and temperature changes for the 21 st century from ensembles of recent AOGCM simulations. Geophys. Res. Lett. 32, L21715.
Giorgi F. and N. Diffenbaugh, 2008. Developing regional climate change scenarios for use in assessment of effects on human health and disease. Clim. Res. 36, 141-151, doi:10.3354/cr00728.

Giorgi F., C. Jones and G. Asrar, 2009. Addressing climate information needs at the regional level: The CORDEX framework. WMO Bulletin 58, 175-183.

Good P., J. A. Lowe and D. P. Rowell, 2009. Understanding uncertainty in future projections for the tropical Atlantic: relationships with the unforced climate. Clim. Dynam. 32, 205-218.

Gordon C., C. Cooper, C. A. Senior, H. Banks, J. M. Gregory, T. C. Johns, J. F .B Mitchell and R. A. Wood, 2000. The simulation of SST, sea ice extent and ocean heat transports in a version of the Hadley Centre coupled model without flux adjustments. Clim. Dynam. 16, 147-168.

Grell G. A., J. Dudhia and D. R. Stauffer, 1993. A description of the fifth-generation Penn System/NCAR Mesoscale Model (MM5). NCAR Technical Note NCAR/TN-398+1A, 107 pp.

Grose M. R., J. N. Brown, S. Narsey, J. R. Brown, B. F. Murphy, C. Langlais, A. S. Gupta, A. F. Moise and D. B. Irving, 2014. Assessment of the CMIP5 global climate model simulations of the western tropical Pacific climate system and comparison to CMIP3. Int. J. Climatol. 34, 3382-3399.

Gulizia C. and I. Camilloni, 2015. Comparative analysis of the ability of a set of CMIP3 and CMIP5 global climate models to represent precipitation in South America. Int. J. Climatol. 35, 583-595, doi: 10.1002/joc.4005.

Hawkins E. and R. T. Sutton, 2009. The potential to narrow uncertainty in regional climate predictions. Bull. Am. Meteorol. Soc. 90, 1095-1107, doi:10.1175/2009BAMS2ensamblede607.1.

Hawkins E. and R. T. Sutton, 2011. The potential to narrow uncertainty in projections of regional precipitation change. Clim. Dynam. 37, 407-418, doi:10.1007/ s00382-010-0810-6.

Hayashi Y., 1982. Confidence intervals of a climatic signal. J. Atmos. Sci. 39,1895-1905, doi:10.1175/15200469(1982)039\1895: CIOACS[2.0.CO;2.

Haylock M. R., T. C. Peterson, L. M. Alves, T. Ambrizzi, Y. M. T. Anunciação, J. Baez, V. R. Barros, M. A. Berlato, M. Bidegain, G. Coronel, V. Corradi, V. J. Garcia, A. M. Grimm, D. Karoly, J. A. Marengo, M. B. Marino, D. F. Moncunill, D. Nechet, J. Quintana, E. Rebello, M. Rusticucci, J. L. Santos, I. Trebejo and L. A. Vincent, 2006. Trends in total and extreme South 
American rainfall 1960-2000 and links with sea surface temperature. J. Climate 19, 1490-1512.

Hewitt C. D., 2005. The ENSEMBLES Project: Providing ensemble-based predictions of climate changes and their impact. EGGS Newsletter 13, 22-25.

Hong S. and H. Pan, 1996. Non-local boundary layer vertical diffusion in a medium-range forecast model. Mon. Weather Rev. 124, 2322-2339.

Hsie E. Y., R. A. Anthes and D. Keyser, 1984. Numerical simulation of frontogenesis in a moist atmosphere. $J$. Atmos. Sci. 41, 2581-2594.

Holland M. M., M. C. Serreze and J. Stroeve, 2010. The sea ice mass budget of the Arctic and its future change as simulated by coupled climate models. Clim. Dynam. 34, 185-200.

Im E.-S., M.-H. Kim, W.-T. Kwon and S. Cocke, 2007. Projected change in mean and extreme climate over Korea from a double-nested regional climate model simulation. J. Meteor. Soc. Jpn. 85, 717-732.

IPCC, 2007. Climate change 2007: The physical science basis. Contribution of Working Group I to the Fourth Assessment Report of the Intergovernmental Panel on Climate Change (S. Solomon, D. Qin, M. Manning, Z. Chen, M. Marquis, K. B. Averyt, M. Tignor and H. L. Miller, Eds.). Cambridge University Press, Cambridge, United Kingdom and New York, 996 pp.

IPCC, 2013. Climate change 2013: The physical science basis. Contribution of Working Group I to the Fifth Assessment Report of the Intergovernmental Panel on Climate Change (T. F. Stocker, D. Qin, G.-K. Plattner, M. Tignor, S. K. Allen, J. Boschung, A. Nauels, Y. Xia, V. Bex and P. M. Midgley, Eds.). Cambridge University Press, Cambridge, United Kingdom and New York, NY, USA, 1535 pp.

Islam M. N., M. Rafiuddin, A. U. Ahmed and R. K. Kolli, 2008. Calibration of PRECIS in employing future scenarios in Bangladesh. Int. J. Climatol. 28, 617-628, doi:10.1002/joc. 1559.

Islam S. and N. Rehman, 2009. Future change in the frequency of warm and cold spells durations over Pakistan simulated by the PRECIS regional climate model. Climatic Change, doi:10.1007/s10584-009-9557-7.

Islam S., N. Rehman and M.M. Sheikh, 2009. Future change in the frequency of warm and cold spells over Pakistan by the PRECIS regional climate model. Climatic Change 94, 35-45.

Jacob D., J. Petersen, B. Eggert, A. Alias, O. B. Christensen, L. M. Bouwer, A. Braun, A. Colette, M. Déqué, G. Georgievski, E. Georgopoulou, A. Gobiet, L. Menut,
G. Nikulin, A. Haensler, N. Hempelmann, C. Jones, K. Keuler, S. Kovats, N. Kröner, S. Kotlarski, A. Kriegsmann, E. Martin, E. van Meijgaard, C. Moseley, S. Pfeifer, S. Preuschmann, C. Radermacher, K. Radtke, D. Rechid, M. Rounsevell, P. Samuelsson, S. Somot, J.-F. Soussana, C. Teichmann, R. Valentini, R. Vautard, B. Weber and P. Yiou, 2013. EURO-CORDEX: New high-resolution climate change projections for European impact research. Reg Environ. Change, doi:10.1007/ s10113-013-0499-2.

Jones P. G. and P. K. Thornton, 2003. The potential impacts of climate change on maize production in Africa and Latin America in 2055. Global Environ. Chang. 13, 51-59.

Kay A. L., H. N. Davies, V. A. Bell and R. G. Jones, 2009. Comparison of uncertainty sources for climate change impacts: Flood frequency in England. Climatic Change 92, 41-63.

Koo G.-S., K.-O. Boo and W.-T. Kwon, 2009. Projection of temperature over Korea using an MM5 regional climate simulation. Clim Res. 40, 241-248, doi:10.3354/ cr00825.

Kotlarski S., A. Block, D. Jacob, K. Keuler, R. Knoche, D. Rechid and A. Walter, 2005. Regional climate model simulations as input for hydrological applications: Evaluation of uncertainties. Adv. Geosci. 5, 119-125.

Krichak S. O., P. Alpert, K. Bassat and P. Kunin, 2007. The surface climatology of the eastern Mediterranean region obtained in a three-member ensemble climate change simulation experiment. Adv. Geosci. 12, 67-80.

Krüger L. F., R. P da Rocha, M. S. Reboita and T. Ambrizzi, 2012. RegCM3 nested in HadAM3 scenarios A2 and B2: Projected changes in extratropical cyclogenesis, temperature and precipitation over the South Atlantic Ocean. Climatic Change 113, 599-621.

Laghari A. N., D. Vanham and W. Rauch, 2012. To what extent does climate change result in a shift in Alpine hydrology? A case study in the Austrian Alps. Hydrolog. Sci. J. 57, 103-117, doi:10.1080/02626667.2011. 637040.

Laprise R., R. de Elía, D. Caya, S. Biner, P. Lucas-Picher, E. Diaconescu, M. Leduc, A. Alexandru, L. Separovic 2008: Challenging some tenets of regional climate modelling. Meteorol. Atmos. Phys. 100, 3-22.

Liang X. Z., L. Li, K. Kunkel, M. Ting and J. X L. Wang, 2004. Regional climate simulations of U.S. precipitation during 1982-2002. Part I: Annual cycle. J. Climate 17, 3510-3529. 
Marengo J. A. and T. Ambrizzi, 2006. Use of regional climate models in impacts assessments and adaptations studies from continental to regional and local scales: The CREAS (Regional Climate Change Scenarios for South America) initiative in South America. Proceedings of the 8th International Conference on Southern Hemisphere Meteorology and Oceanography, Foz do Iguaçu, Brazil, 24-28 April, pp. 291-296.

Marengo J. A., R. Jones, L. M. Alves and M. C. Valverde, 2009. Future change of temperature and precipitation extremes in South America as derived from the PRECIS regional climate modeling system. Int. J. Climatol 29, 2241-2255.

Marengo J. A., T. Ambrizzi, R. da Rocha, L. M. Alves, S. V. Cuadra, M. C. Valverde, R. R. Torres, D. C. Santos and S. E. T. Ferraz, 2010. Future change of climate in South America in the late twenty-first century: Intercomparison of scenarios from three regional climate models. Clim. Dynam., doi:10.1007/s00382-009-0721-6.

Marengo J. A., S. C. Chou, G. Kay, L. M. Alves, J. F. Pesquero, W. R. Soares, D. C. Santos, A. A. Lyra, G. Sueiro, R. Betts, D. J. Chagas, J. L. Gomes, J. F. Bustamante and P. Tavares, 2012. Development of regional future climate change scenarios in South America using the Eta CPTEC/HadCM3 climate change projections: Climatology and regional analyses for the Amazon, Sao Francisco and the Parana River basins. Clim. Dynam. 38, 1829-1848, doi:10.1007/ s00382-011-1155-5.

Meehl G. A., H. Teng and G. Branstator, 2006. Future changes of El Niño in two global coupled climate models. Clim. Dynam. 26, 549-566, doi:10.1007/ s00382-005-0098-0.

Meehl G. A., C. Covey, T. Delworth, L. Mojib, B. McAvaney, J. F. B. Mitchell, R. J. Stouffer and K. E. Taylor, 2007a. The WCRP CMIP3 multimodel dataset: A new era in climate change research. Bull. Am. Meteorol. Soc. 88, 1383-1394, doi:10.1175/ BAMS- 88-9-1383.

Meehl G. A., T. F. Stocker, W. D. Collins, P. Friedlingstein, A. T. Gaye and J. M. Gregory, 2007b. Global climate projections. In: Climate change 2007: The physical science basis. Contribution of Working Group I to the Fourth Assessment Report of the Intergovernmental Panel on Climate Change (S. Solomon, D. Qin, M. Manning, Z. Chen, M. Marquis, K. B. Averyt, M. Tignor and H. L. Miller, Eds.). Cambridge University Press, Cambridge, United Kingdom and New York, 747-843.
Mitchell T. and M. Hulme, 1999. Predicting regional climate change: Living with uncertainty. Prog. Phys. Geog. 23, 57-78.

Mizuta R., K. Oouchi, H. Koshimura, A. Noda, K. Katayama, S. Yukimoto, M. Hosaka, S. Kusunoki, H. Kawai and M. Nakagawa, 2006. 20-km-Mesh global climate simulations using JMA-GSM Model -mean climate states-. J. Meteor. Soc. Jpn. 84, 165-185.

Monier E., J. R. Scott, A. P. Sokolov, C. E. Forest and C. A. Schlosser, 2013. An integrated assessment modelling framework for uncertainty studies in global and regional climate change: The MIT IGSM-CAM (version 1.0). Geosci. Model. Dev. Discuss. 6, 2213-2248, doi:10.5194/gmdd-6-2213-2013.

Núñez M. N., S. A. Solman and M. F. Cabré, 2008. Regional climate change experiments over Southern South America. II: Climate change scenarios in the late twenty first century. Clim. Dynam. 32,1081-1095.

Núñez M. N. and J. Blázquez, 2014. Climate change in La Plata basin as seen by a high-resolution global model. Atmospheric and Climate Sciences 4, 272-289.

Pan Z., J. H. Christensen, R. W. Arritt, W. J. Gutowski Jr., E. S. Takle and F. Otieno, 2001. Evaluation of uncertainties in regional climate change simulations. J. Geophys. Res. 106, 17735-17751.

Pieczka I., R. Pongrácz and J. Bartholy, 2011. Comparison of simulated trends of regional climate change in the Carpathian basin for the 21 st century using three different emission scenarios Acta Silv. Lign. Hung. 7, 9-22.

Pope V. D., M. L. Gallani, P. R. Rowntree and R. A. Stratton, 2000. The impact of new physical parameterizations in the Hadley Centre climate model. Clim. Dynam. 16, 123-146, doi:10.1007/s003820050009.

Räisänen J., 2006. How reliable are climate models? Tellus A 59, 2-29.

Randall D., R. Wood, S. Bony, R. Colman, T. Fichefet, J. Fyfe, V. Kattsov, A. Pitman, J. Shukla, J. Srinivasan, R. Stouffer, A Sumi and K. Taylor, 2007. In: Climate models and their evaluation. Contribution of Working Group I to the Fourth Assessment Report of the Intergovernmental Panel on Climate Change (S. Solomon, D. Qin, M. Manning, Z. Chen, M. Marquis, K. Averyt, M. Tignor and H. Miller, Eds.). Cambridge University Press, Cambridge, United Kingdom and New York, NY, USA.

Rayner N. A., D. E. Parker, E. B. Horton, C. K. Folland, L. V. Alexander, D. P. Rowel, E. C. Kent and A. Kaplan, 2003. Global analyses of SST, sea ice, and night marine air temperature since the late nineteenth century. $J$. Geophys. Res. 108, 4407, doi:10.1029/2002JD002670. 
Reboita M. S., R. P. da Rocha, C. G. Dias and R. Y. Yenoue, 2014. Climate projections for South America: RegCM3 driven by HadCM3 and ECHAM5. Advances in Meteorolgy, 376738, doi:10.1155/2014/376738.

Rummukainen M., 2010. State-of-the-art with regional climate models. Wiley Interdisciplinary Reviews: Climate Change 1, 82-96.

Rupa Kumar K., A. K. Sahai, K. Krisma Kumar, S. K. Patwardhan, P. K. Mishra, J. V. Revadekar, K. Kamala and G. B. Pant, 2006. High-resolution climate change scenarios for India for the $21^{\text {st }}$ century. Curr. Sci. 90, 334-345.

Rupp D. E., J. T. Abatzoglou, K. C. Hegewisch and P. W. Mote, 2013. Evaluation of CMIP5 $20^{\text {th }}$ century climate simulations for the Pacific Northwest USA.J. Geophys. Res.-Atmos. 118, 10884-10906, doi:10.1002/jgrd.50843.

Saeed F., A. Haensler, T. Weber, S. Hagemann and D. Jacob, 2013. Representation of extreme precipitation events leading to opposite climate change signals over the Congo basin. Atmosphere 4, 254-271; doi:10.3390/ atmos4030254.

Sánchez E., S. A. Solman, R. C. Remedio, H. Berbery, P. Samuelsson, R. P. Da Rocha, C. Mourão, L. Li, J. Marengo, M. de Castro and D. Jacob, 2015. Regional climate modelling in CLARISLPB: A concerted approach towards twentyfirst century projections of regional temperature and precipitation over South America. Clim. Dynam. 45, 2193-2212, doi:10.1007/ s00382-014-2466-0.

SAYDS, 2014. Cambio climático en Argentina; tendencias y proyecciones. Tercera comunicación nacional sobre cambio climático a la Convención Marco de las Naciones Unidas sobre Cambio Climático. Secretaría de Ambiente y Desarrollo Sustentable de la Nación-Centro de Investigaciones del Mar y la Atmósfera. Buenos Aires, Argentina.

Soares W. and J. A. Marengo, 2009. Assessments of moisture fluxes east of the Andes in South America in a global warming scenario. Int. J. Climatol. 29, 13951414, doi: 10.1002/joc.1800.

Solman S. A., M. F. Cabré and M. N. Nuñez, 2007. Regional climate change experiments over southern South America: I: Present climate. Clim. Dynam. 30, 533-552, doi:10.1007/s00382-007-0304-3.

Solman S. A., 2013. Regional climate modeling over South America: A review. Advances in Meteorology, 504357, doi:10.1155/2013/504357.

Solman S. A., E. Sánchez, P. Samuelson, R. da Rocha, L. Li, J. Marengo, N. Pessacg, A. R. C. Remedio, S. C. Chou, H. Berbery, H. Le Treut, M. de Castro and D.
Jacob, 2013. Evaluation of an ensemble of regional climate model simulations over South America driven by the ERA-Interim reanalysis: Model performance and uncertainties. Clim. Dynam., doi:10.1007/s00382013-1667-2.

Sörensson A., C. G. Menéndez, R. Ruscica, P. Alexander, P. Samuelsson and U. Willen, 2010. Projected precipitation changes in South America: A dynamical downscaling within CLARIS. Meteorol. Z 19, 347-355

Stephens G. L., 1978. Radiation profiles in extended water clouds: II. Parameterization schemes. J. Atmos. Sci. 35, 2123-2132.

Stephens G. L., 1984. The parameterization of radiation for numerical weather prediction and climate models. Mon. Weather Rev. 112, 826-867.

Tadross M. A., C. Jack and B. C. Hewitson, 2005. On RCM-based projections of change in southern African summer climate. Geophys. Res. Lett. 32, L23713, doi:10.1029/2005GL024460.

Tapiador F. J. and E. Sánchez, 2008. Changes in the European precipitation climatologies as derived by an ensemble of regional models. J. Climate 21, 2540-2557.

Taylor K. E., R. J. Stouffer, G. A. Meehl, 2012. An overview of CMIP5 and the experiment design. Bull. Am. Meteorol. Soc. 93, 485-498, doi:10.1175/ BAMS-D-11-00094.1.

Teichmann C., B. Eggert, A. Elizalde, A. Haensler, D. Jacob, P. Kumar, C. Moseley, S. Pfeifer, D. Rechid, A. R. Remedio, H. Ries, J. Petersen, S. Preuschmann, T. Raub, F. Saeed, K. Sieck and T. Weber, 2013. How does a regional climate model modify the projected climate change signal of the driving GCM: A study over different CORDEX regions using REMO. Atmosphere 4, 214-236; doi:10.3390/atmos4020214.

Torres R. R. and J. A. Marengo, 2013. Uncertainty assessments of climate change projections over South America. Theor. Appl. Climatol. 112, 253-272, doi:10.1007/ s00704-012-0718-7.

Urrutia R. and M. Viulle, 2009. Climate change projections for the tropical Andes using a regional climate model: Temperature and precipitation simulations for the end of the $21^{\text {st }}$ century. J. Geophys. Res. Atmos. 114, D02108.

Vera C. and G. Silvestri, 2009. Precipitation interannual variability in South America from the WCRP-CMIP3 multi-model dataset. Clim. Dynam. 32, 1003-1014, doi:10.1007/s00382-009-0534-7

Vizcaíno M., U. Mikolajewicz, J. Jungclaus and G. Schurgers, 2010. Climate modification by future ice sheet 
changes and consequences for ice sheet mass balance. Clim. Dynam. 34, 301-324.

Whetton P. H., J. J. Katzfey, K. J. Hennessy, X Wu, J. L. McGregor and K. Nguyen, 2001. Developing scenarios of climate change for Southeastern Australia: An example using regional climate model output. Clim. Res. 6, 181-201.
Wiens J. A., D. Stralberg, D. Jongsomjit, C. A. Howell and M. A. Snyder, 2009. Niches, models, and climate change: Assessing the assumptions and uncertainties. P. Natl. Acad. Sci. USA 106, 19729-19736.

Wood A. W., L. R. Leung, V. Sridhar and D. P. Lettenmaier, 2004. Hydrologic implications of dynamical and statistical downscaling approaches to downscaling climate model outputs, Climatic Change 62, 189-216. 